DEMOGRAPHIC RESEARCH

VOLUME 32, ARTICLE 32, PAGES 873-914 PUBLISHED 8 MAY 2015

http://www.demographic-research.org/Volumes/Vol32/32/

DOI: 10.4054/DemRes.2015.32.32

Research Article

\title{
Traditional and modern cohabitation in Latin America: A comparative typology
}

Maira Covre-Sussai

Bart Meuleman

Sarah Botterman

Koen Matthijs

C2015 Covre-Sussai, Meuleman, Botterman \& Matthijs.

This open-access work is published under the terms of the Creative Commons Attribution NonCommercial License 2.0 Germany, which permits use, reproduction \& distribution in any medium for non-commercial purposes, provided the original author(s) and source are given credit.

See http:// creativecommons.org/licenses/by-nc/2.0/de/ 


\section{Table of Contents}

$\begin{array}{lll}1 & \text { Introduction } & 874\end{array}$

2 Cohabitation in Latin America: Empirical evidence and theoretical 876 explanation

3 Traditional vs. modern types of cohabitation: An empirical 881 hypothesis

$4 \quad$ Research method $\quad 882$

4.1 Data: Demographic and Health Survey 882

$\begin{array}{lll}4.2 & \text { Variables } & 883\end{array}$

$\begin{array}{lll}4.3 & \text { Method } & 885\end{array}$

$5 \quad$ Results $\quad 886$

$\begin{array}{llr}6 & \text { Conclusion } & 898\end{array}$

$\begin{array}{ll}\text { References } & 902\end{array}$

Appendix 1: Data description $\quad 907$

Appendix 2: Multiple Group Latent Class Analysis 911

Appendix 3: Item response and types of cohabitation probability 914 (1980s and 1990s) 


\title{
Traditional and modern cohabitation in Latin America: A comparative typology
}

\author{
Maira Covre-Sussai ${ }^{1}$ \\ Bart Meuleman ${ }^{2}$ \\ Sarah Botterman ${ }^{3}$ \\ Koen Matthijs ${ }^{4}$
}

\begin{abstract}
BACKGROUND

The existence of cohabitation is a historical feature of nuptiality in Latin America. Traditionally, cohabitation was common in less developed regions, among the lower social classes. But today its occurrence is increasing and in social groups and regions in which it was not common. The features of this latter type of cohabitation remain unclear.
\end{abstract}

\section{OBJECTIVE}

We differentiate types of cohabitation in Latin America on the basis of relationship context at its outset and its outcomes in terms of childbearing. The comparability of these types over countries is attested, as well as their evolution over time and the educational and age profiles of cohabitants.

\section{METHODS}

Demographic and Health Survey data for the 1980s, 1990s, and 2000s for up to eight countries are analyzed by means of Multiple Group Latent Class Analysis.

\section{RESULTS}

Three types of cohabitation are found. The traditional type includes young and lowereducated women who start to cohabit during adolescence. They have more children at younger ages. The remaining two types of cohabitation included higher-educated women and are considered modern. The innovative type groups women from all age groups, with fewer children born at a higher age and never as a single woman. Blended

\footnotetext{
${ }^{1}$ Katholieke Universiteit Leuven, Belgium and National School of Statistics (ENCE/IBGE - Bolsista CNPq), Rio de Janeiro, Brazil. E-Mail: mairacovre@gmail.com.

${ }^{2}$ Katholieke Universiteit Leuven, Belgium.

${ }^{3}$ Katholieke Universiteit Leuven, Belgium

${ }^{4}$ Katholieke Universiteit Leuven, Belgium
} 
cohabitation refers to older women, who could negotiate a marriage, but do not. They start to cohabit during adulthood, but always after single pregnancy.

\section{CONCLUSIONS}

The persistence of historical trends is attested. Traditional cohabitation is related to socioeconomic deprivation and prevails in Central American and Caribbean countries. However, two modern types of cohabitation are emerging in the region. They are concentrated in the South and related to women's independence.

\section{Introduction}

Patterns of family formation have changed markedly over the past decades in the West. Economic, technological, social, and ideational changes have led to significant transformations in family life, such as union formation, union stability, and gender relations. In developed countries, new forms of living arrangement, especially unmarried cohabitation, are interpreted as outcomes of the modernization process, female economic independence, and the rising symmetry in gender roles (van de Kaa 1987). Recent evidence has shown that cohabitation in the West is also related to economic deprivation and has been used as an alternative to marriage by people with few economic resources or poor economic expectations (e.g., Hiekel et al. 2012; Kalmijn 2011; Kiernan et al. 2011 [for European results]; Sassler and Miller 2011; Bumpass et al. 1991 [results for the US]).

Although the rise in consensual unions is present in developed countries as well as in Latin American countries, the features of these unions can differ. This study seeks to contribute to the existing literature by investigating the types of cohabitation that exist in Latin America, as well as their prevalence, main characteristics, and evolution through time. Therefore we differentiate types of cohabitation on the basis of the relationship context at their beginning (woman's age and occurrence of pre-cohabitation pregnancy or childbearing) and their outcomes in terms of childbearing (number of children and mother's age at birth of first child).

The coexistence of marriage and cohabitation is a historical feature of nuptiality in Latin America (Castro-Martin 2002). Cohabitation has always been marked by high fertility, it was most prevalent in rural regions and among the lower and less-educated social classes (Parrado and Tienda 1997). Today, there is evidence that another type of cohabitation is coming into existence alongside traditional cohabitation in the region (e.g., Castro-Martin 2002; Esteve et al. 2012). Yet the exact interpretation of this new type of cohabitation, often characterized as a more modern type of union formation, remains unclear. Indications exist illustrating that this type of cohabitation is closely 
linked to the consensual union practiced by higher-educated groups in Western developed countries ${ }^{5}$ (Binstock and Cabella 2011 ${ }^{6}$; Parrado and Tienda $1997^{7}$ ), where cohabitation is usually a childless period, an alternative to marriage or singlehood, and more visible among younger cohorts (Heuveline and Timberlake 2004; Kiernan 2004). Thus, in Latin America, the choice of cohabiting instead of getting married could be related to either tradition or modernity.

Although several studies have explored different types of cohabitation in Latin America (i.e., Castro-Martin 2002; Esteve et al. 2012; Parrado and Tienda 1997), none of them empirically differentiate the traditional type of consensual union from the modern type. In addition, no research has been found which illustrates how these types of cohabitation develop over time in the region. This study seeks to bridge this gap by examining whether it is possible to differentiate types of cohabitation through information on union formation and childbearing. Next, how these types of cohabitation develop over time in different Latin American contexts is verified. In addition, this study assesses whether the prevalence of the different types of consensual union varies across different family structures (extended, composite, or nuclear), women's age, and educational groups.

For this purpose we use data about first cohabitations ${ }^{8}$ from the Demographic and Health Survey (DHS) for eight Latin American countries (i.e., Brazil, Bolivia, Colombia, Dominican Republic, Guyana, Honduras, Nicaragua, and Peru). Additionally, since these countries are quite heterogeneous in terms of colonization history, socioeconomic development, and spoken language, we compare the different types of consensual union across these countries. Before abstract constructs can be compared in a valid cross-country comparison it must be demonstrated that the concepts are measured in an equivalent or invariant way (Horn and McArdle 1992; Johnson 1998). We used multiple group latent class analysis (MGLCA) (Kankaras et al. 2010; McCutcheon 2002) to test the cross-country comparability of our typology of cohabitation. Research indicates that this is the first empirical attempt to disentangle the different types of cohabitation over time in Latin America taking the issue of measurement invariance into account.

In the following section we discuss the Second Demographic Transition (SDT) theory that is often used to explain the rise in cohabitation among higher-educated groups in developed countries and its potential in the Latin American context. Next, the

\footnotetext{
${ }^{5}$ For an empirical update of the meanings of cohabitation in Europe see Hiekel et al. (2012), for the United States Manning and Cohen (2012).

${ }^{6}$ Results for Argentina, Chile, and Uruguay.

${ }^{7}$ Results for Caracas, Venezuela.

${ }^{8}$ The choice of first cohabitations was made due to data limitations and because the relationship context at the beginning of the relationship, as well as its outcomes in terms of childbearing, are very different for second or higher order unions than for first unions (Brown 2000).
} 
dataset is described as well as the operationalization of the observed indicators of different types of cohabitation and its covariates. Subsequently the outcomes of the MGLCA-model are presented, followed by a discussion of the results and implications of our findings for the study on nuptiality in Latin America.

\section{Cohabitation in Latin America: Empirical evidence and theoretical explanation}

Latin America has witnessed a significant increase in cohabitation since the 1970s. This increase is visible among all social groups. It includes higher social classes and highereducated women in countries where this type of union used not to be commonplace (Castro-Martin 2002; Esteve et al. 2012). This more innovative type of cohabitation has been related to women's increasing autonomy in countries where economic development is at a more advanced stage in comparison to others (Binstock and Cabella 2011; Quilodrán-Salgado 2011). This is the case in the region called the Southern Cone (Argentina, Chile, and Uruguay - Binstock and Cabella 2011) and the southern regions of Brazil (Covre-Sussai and Matthijs 2010). At the same time, the traditional type of cohabitation among lower-educated women is a persistent feature of nuptiality in Latin America (Castro-Martin 2002). This type of cohabitation is more visible in less developed places, mainly in Caribbean and Central American countries.

In order to understand the coexistence of different types of cohabitation in Latin America it is important to compare and contrast historical and contemporary evidence about traditional cohabitation in the region, as well as to understand Latin American heterogeneity.

Latin America is a heterogeneous region in terms of socioeconomic development and ethnic composition. Socioeconomic differences within countries can be illustrated by the GINI Index, while the Human Development Index (HDI) demonstrates their socioeconomic development. With the exception of Haiti, the HDI has increased in all Latin American countries during the last decades. In 2010, while the majority of the countries (i.e., Argentina, Brazil, Chile, Costa Rica, Colombia, Ecuador Uruguay, Mexico, Panama, Peru, and Venezuela) saw their HDI increase from medium to high, some of them improved from low to a medium level (i.e., Bolivia, Dominican Republic, El Salvador, Guatemala, Guyana, Honduras, Nicaragua, Paraguay, and Suriname). At the same time, inequality is still one of the main features of the region, with the GINI coefficients ranging from a minimum of 0.43 in Guatemala to more than 0.59 in Haiti.

In terms of ethnic composition, while many countries are marked by the presence of the indigenous population, in other countries such groups are very few. On the other hand European and African populations have immigrated into the region over the 
centuries, and miscegenation has created numerous racial groups within and across national boundaries. While some countries present certain homogeneity in their ethnic composition, others are marked by ethnic diversity and internal miscegenation. The former is the case of Argentina, Costa Rica, and Uruguay, where people of European descent (whites) predominate, and the latter of Peru, Bolivia, and Guatemala, where there are high proportions of Amerindians (Heaton et al. 2002).

The historical roots of traditional cohabitation, as a distinguishing attribute of Latin American nuptiality, date back to colonial times (late $15^{\text {th }}$ to early $19^{\text {th }}$ centuries). While the white colonial settlers (Portuguese and Spanish) introduced the European pattern of marriage to Latin America, native indigenous and African descent populations had very different forms of union formation.

For the white upper classes from colonial times until the middle of the $20^{\text {th }}$ century the institution of marriage was highly valorized and based on hierarchic, authoritarian, and patriarchal relationships. In this context family relations were marked by submission to the father/husband, control of female sexuality, and the concept of family honor. The control over female sexuality was intensified by ethnic and class differences. Historically, while women from the upper classes needed to submit themselves to arranged marriages, men were allowed to have relationships with women from different social and ethnic groups, following different rationalities and moral codes (Arriagada 2002). Traditionally, women from the same (upper) social class and ethnicity (white) were 'to be married to', although extra-marital relationships (concubinage) with women from lower social classes and different ethnic groups were common (Caulfield 2001; Fernández-Aceves 2007).

The majority of native indigenous populations have union formation patterns that differ greatly from the European concept of marriage. When Portuguese and Spanish settlers arrived in the region they found a native population that was usually polygamous, practicing either polygyny or polyandry (Ribeiro 1997). With the introduction of slavery economies in Latin America (from the $16^{\text {th }}$ to the $19^{\text {th }}$ century), and the refusal of indigenous populations to become slaves, slaves from different parts of the African continent were introduced into several areas of the region (Ribeiro 1997). As slaves they had to submit themselves to the rules set by their European masters, as well as suffer very difficult living conditions. Apart from forced labor and following the patriarchal model of the family in the region at that time, female slaves were commonly submitted to non-consensual sexual relationships with their owners and/or owner's sons (e.g., Freyre 2000; Ribeiro 1997). At that time a Roman Catholic marriage was the only 'official' marriage in the region, and the Catholic Church and local governments encouraged marriage among slaves and converted indigenous populations. However, slaveholders restricted legal marriage among slaves due to the difficulty of selling married individuals separately (Holt 2005). In addition, in Latin American colonial 
times, runaway or freed black populations, native indigenes, poor whites, and their (quite often mixed race) descendants were indifferent to marriage.

Samara and Costa (1997) interpret this indifference to marriage in Brazil as a type of rebellion, resistance, or insubordination of the marginalized segments of the colonial society. The refusal by lower social classes in Brazil to marry is understood as a response to social exclusion, an attempt to behave differently from the upper classes and create independent forms of organization (Samara and Costa 1997). According to Samara and Costa, "celibacy, cohabitation, mistresses, and illegitimate children can mean resistance in a context where the church and the local authorities were removed from the daily needs of the people" (Samara and Costa 1997, p. 224). In the meantime, considering that marriage was highly valorized by the upper social class, the same authors argue that marriage was also used as a strategy of upward social mobility for some marginalized groups in Latin American societies (Samara and Costa 1997).

William J. Goode reviewed the ethnographic literature on the prevalence of consensual unions and illegitimacy in the Caribbean up to 1960 and understood the phenomena in a different way. According to his analysis, since unions based on marriage obtain more social respect and are preferable to other types of union, there is no 'counter-norm' or special approval of cohabitation in Caribbean societies (Goode 1960, 1961). However, Goode also highlighted that lower social classes were less committed than the middle or upper strata to the legitimation of their unions (Goode 1960). Considering that the costs of marriage are higher than those of cohabitation (for instance, marriage demands ceremony and a party as expressions of community validation or as a 'rite of passage'), couples tend to live in consensual unions for a period of time and get married when their financial situations improve or separate if their economic situations worsen.

Interpretations found in contemporary literature about traditional cohabitation are not very different from the analyses of Goode. Nowadays, traditional cohabitation is considered an alternative to marriage and is practiced as a strategy to cope with the hardships of poverty and single, sometimes adolescent pregnancy or childbearing. Faced with the responsibility of taking care of younger brothers and sisters, or suffering domestic violence from their fathers or step fathers, young women from the lower social classes tend to prefer to live together in a cohabiting union to waiting and 'negotiating' a marriage. The problem with this 'solution' is that in most cases it does not improve the socioeconomic situation of these women. Contrarily, in cases of separation, women are often responsible not only for their livelihood but also for the care for their children (Arriagada 2002). This situation contributes to the incidence of households headed by women in Latin America. These types of household have been related to the feminization of poverty in the region (Arriagada 2002; García and de Oliveira 2011). 
Greene and Rao (1995) used Brazilian data beginning in the 1960s and going into the 1980s to analyze the increasing incidence of cohabitation, the chances of living in cohabitation instead of being married, and the likelihood of choosing marriage or cohabitation instead of remaining single. The authors found that the increasing incidence of consensual unions, already significant in the $1980 \mathrm{~s}$, is a solution to the marriage squeeze in Brazilian society. Faced with an imbalanced sex ratio that leads to a greater proportion of women on the marriage market, Brazilian men tend to be 'recycled' through several unions. According to Greene and Rao, because cohabitation is easier to dissolve there was an increase in this type of union. Since this interpretation is only consistent for lower-educated women (those that are now called traditional cohabitants), the authors understand that higher-educated women are able to negotiate a marriage, which is preferable and provides greater institutional protection than cohabiting unions (Greene and Rao 1995).

Considering the historical roots of cohabitation in Latin America and the recent socioeconomic developments that have occurred in the region, a decline in the incidence of consensual unions could be expected. However, contemporary research indicates an accentuation of the occurrence of cohabitation among the lower social strata combined with an unprecedented increase in the proportion of cohabitants among higher-educated groups. Meanwhile, the meaning of cohabitation for the Latin American higher social classes remains unclear. Some researchers suggest that the connotation of consensual unions by higher social classes is closer to those observed in cohabitations by higher-educated groups in developed countries, denoting a trial period before marriage or an alternative to singlehood (Binstock and Cabella 2011; Esteve et al. 2012; Parrado and Tienda 1997).

Table 1 presents the evolution of the propensity of partnered women to live in cohabitation instead of being married in several age groups for the Latin American countries covered by this study. 
Covre-Sussai et al.: Traditional and modern cohabitation in Latin America

Table 1: Women living in consensual unions instead of in marriages in Latin America

\begin{tabular}{|c|c|c|c|c|c|c|c|c|c|c|c|c|}
\hline \multirow{2}{*}{$\begin{array}{l}\text { Age } \\
\text { group }\end{array}$} & \multicolumn{2}{|c|}{ Bolivia } & \multicolumn{3}{|c|}{ Brazil } & \multicolumn{3}{|c|}{ Colombia } & \multicolumn{4}{|c|}{ Nicaragua } \\
\hline & 1989 & 2008 & $\Delta \%$ & 1970 & 2010 & $\Delta \%$ & 1970 & 2005 & $\Delta \%$ & 1971 & 2005 & $\Delta \%$ \\
\hline 15-19 & 6.1 & 11.6 & 90.2 & 11.5 & 81.1 & 604.6 & 33.6 & 89.4 & 166.0 & 57.9 & 80.9 & 39.8 \\
\hline $20-24$ & 18.8 & 31.4 & 67.0 & 8.3 & 63.2 & 661.8 & 24.2 & 79.7 & 229.1 & 47.5 & 65.9 & 38.6 \\
\hline 5-29 & 15.7 & 33.8 & 115.3 & 7.5 & 51.0 & 579.6 & 19.7 & 67.4 & 242.9 & 42.8 & 55.5 & 29.6 \\
\hline 30-34 & 9.4 & 26.2 & 178.7 & 7.1 & 43.4 & 511.0 & 18.2 & 58.3 & 220.3 & 36.0 & 49.4 & 37.0 \\
\hline 35-39 & 10.2 & 19.3 & 89.2 & 7.0 & 37.5 & 433.3 & 17.7 & 51.2 & 190.1 & 36.1 & 44.4 & 22.8 \\
\hline $40-44$ & 6.8 & 17.3 & 154.4 & 6.7 & 31.9 & 374.3 & 15.9 & 45.2 & 184.1 & 31.8 & 40.9 & 28.6 \\
\hline $45-49$ & 5.9 & 13.9 & 135.6 & 6.1 & 26.6 & 333.5 & 14.6 & 40.5 & 177.6 & 29.6 & 36.5 & 23.3 \\
\hline 50-54 & & & & 5.7 & 21.8 & 281.0 & 13.2 & 34.7 & 162.8 & 26.6 & 31.4 & 18.0 \\
\hline 55-59 & & & & 4.6 & 17.4 & 276.5 & 12.5 & 29.6 & 137.5 & 22.5 & 26.9 & 19.4 \\
\hline $60+$ & & & & 4.2 & 11.9 & 186.5 & 13.0 & 22.9 & 75.8 & 22.5 & 23.1 & 2.5 \\
\hline \multirow{2}{*}{$\begin{array}{l}\text { Age } \\
\text { group }\end{array}$} & \multicolumn{5}{|c|}{ Dominican Republic Guyana } & \multicolumn{4}{|c|}{ Honduras } & \multicolumn{2}{|l|}{ Peru } & \\
\hline & 1970 & 2007 & $\Delta \%$ & 2002 & 2009 & $\Delta \%$ & 1974 & 2001 & $\Delta \%$ & 1972 & 2007 & $\Delta \%$ \\
\hline 15-19 & 16.4 & 18.1 & 10.4 & 10.6 & 11.5 & 8.5 & 16.8 & 17.2 & 2.4 & 8.3 & 13.2 & 59.0 \\
\hline $20-24$ & 36.3 & 41.1 & 13.2 & 34.7 & 28.0 & -19.3 & 37.4 & 35.9 & -4.0 & 21.0 & 37.0 & 76.2 \\
\hline $25-29$ & 40.8 & 51.8 & 27.0 & 31.7 & 34.6 & 9.1 & 42.9 & 39.3 & -8.4 & 22.8 & 44.0 & 93.0 \\
\hline 30-34 & 39.2 & 54.0 & 37.8 & 29.9 & 33.0 & 10.4 & 42.4 & 37.8 & -10.8 & 21.0 & 40.8 & 94.3 \\
\hline 35-39 & 36.1 & 51.1 & 41.6 & 24.8 & 27.1 & 9.3 & 40.8 & 35.0 & -14.2 & 19.9 & 35.2 & 76.9 \\
\hline $40-44$ & 30.7 & 46.0 & 49.8 & 19.6 & 24.3 & 24.0 & 36.1 & 31.3 & -13.3 & 17.2 & 28.2 & 64.0 \\
\hline $45-49$ & 25.7 & 43.9 & 70.8 & 15.9 & 20.3 & 27.7 & 32.5 & 29.2 & -10.2 & 15.4 & 22.6 & 46.8 \\
\hline 50-54 & 21.5 & & & 12.6 & & & 26.4 & 25.8 & -2.3 & 13.6 & 17.3 & 27.2 \\
\hline 55-59 & 18.0 & & & 6.7 & & & 21.9 & 22.9 & 4.6 & 11.6 & 13.8 & 19.0 \\
\hline $60+$ & & & & & & & & & & & & \\
\hline
\end{tabular}

Source: For Brazil, Colombia and Nicaragua, IPUMS data (Minnesota Population Center 2011), own calculations. For the remaining countries and years, World Marriage Data (United Nations, Department of Economic and Social Affairs 2013).

This table is revealing in several ways. First, the increase in the propensity to live in cohabitation instead of being married is evident for almost all age groups. Second, the speed of increase is faster in countries where the incidence of consensual union has been historically low. Brazil, for example, was among the countries with lower levels of cohabitation in 1970. This country has experienced an approximate increase of $600 \%$ in the incidence of cohabitation among the younger cohorts, and has recently become among the countries with higher levels of cohabitation in these groups. And, finally, the probability of being in a consensual union rose in all countries. Even in Nicaragua, 
which already presented an incidence of cohabitation as high as $58 \%$ in 1970 , the incidence of cohabitation increased by $40 \%$ in three decades. Honduras is an exception and presents a decrease in the inclination to cohabit in almost all age groups.

Although new generations in Latin America are more likely to live in a consensual union, the meaning attached to this increase remains unclear. The literature on family formation and changes points to strong differences between countries and social groups. For the lower social strata, cohabitation is traditionally a substitute for marriage, related to economic constraints and ethnic and gender inequality. At the same time, for the upper social classes it has been suggested that cohabitation is the outcome of modernization and the improved socioeconomic status of women (Binstock and Cabella 2011; Castro-Martin 2002; Vignoli-Rodríguez 2005).

This leads us to the hypothesis that there are different types of cohabitation in Latin America, traditional and modern. The traditional type is related to social exclusion and inequalities, while the modern type is linked to socioeconomic development and can be explained by the Second Demographic Transition (SDT) theoretical framework. The SDT framework is commonly used to explain the wave of changes in norms and attitudes that have transpired in most Western developed countries since the 1960s. Since the first study of the SDT (Lesthaeghe and van de Kaa 1987), the spread of innovative forms of living arrangement (such as cohabitation) is considered an expression not only of changing socioeconomic circumstances or expanding female employment but also as the outcome of secular and anti-authoritarian sentiments of younger and better-educated cohorts (Lesthaeghe 2010; Surkyn and Lesthaeghe 2004). Economic development, increasing educational opportunities, women's autonomy, and desire for self-fulfillment and individualization are considered the main determinants of changes in demographic behavior (van de Kaa 1987).

Although some studies have suggested a division of cohabitation in Latin America into two (Binstock and Cabella 2011; Binstock 2010; Esteve et al. 2012; Parrado and Tienda 1997), empirical differentiation between them is still lacking.

\section{Traditional vs. modern types of cohabitation: An empirical hypothesis}

The traditional type of cohabitation in Latin America is considered to be the result of social inequality. This type of consensual union is generally associated with a high level of fertility, a low level of female independence, and a high employment rate for women in unskilled or domestic jobs. Thus cohabitation is not considered a 'choice', but a constraint imposed upon women who have relatively little bargaining power compared to men (Greene and Rao 1995; Parrado and Tienda 1997). As an alternative to marriage, 
this type of cohabitation could be considered a strategy for women to cope with the problems related to poverty, such as the need to take care of younger brothers and sisters and single (and adolescent) motherhood (Arriagada 2002).

At the same time, there is a lack of information about the modern types of cohabitation. They have been related to the increasing autonomy of women in certain social groups (Binstock and Cabella 2011; Covre-Sussai and Matthijs 2010; Esteve et al. 2012; Parrado and Tienda 1997) as well as to changes in values and attitudes (Esteve et al. 2012). However, no study exists that empirically differentiates between modern and traditional cohabitations.

Therefore, we expect traditional cohabitation to group women who cohabit at very young ages, have a higher incidence of pregnancy prior to cohabitation, bear children at a younger age (of the mother), and bear more children in general. Conversely, we expect the modern type of cohabitation to group women who begin to cohabit during early adulthood, have a lower incidence of pregnancy prior to cohabiting, bear children at older ages (for the mother), and bear fewer children in general.

We also expect traditional cohabitants to be less educated than modern cohabitants and to live within three-generation families or other types of extended household. The traditional type of cohabitation is found to turn into marriage with time (De Vos 1998); therefore we expect to find younger women living in this type of cohabitation. By contrast, it is expected that the modern form of cohabitation will be more related to higher-educated women who live in nuclear families. Because these are highereducated women they are more able to provide for themselves and their children and are in less need of institutional protection. Consequently, we expect to find women from all age groups in the modern type.

\section{Research method}

\subsection{Data: Demographic and Health Survey}

The main research questions are addressed by means of the most recent data from the Demographic and Health Survey (DHS) collected for Latin American countries. These data range from 2001 in Nicaragua to 2010 in Colombia and are labeled 2000s. DHS are nationally representative surveys which collect comparable data on demographic and health issues in developing countries (Rutstein and Rojas 2003). The surveys focus on women in their reproductive ages (15-49 years old). Consistent data on timing and type of first union and complete childbearing histories are available. However, information on transitions to second or higher-order relationships is not. Accordingly, it 
is possible to draw and compute accurate information about first unions, such as age at cohabitation and pre-cohabitation pregnancy, but not about higher-order unions.

Considering this limitation and the fact that this is the first attempt to classify Latin American cohabitation, we decided to narrow the focus of our analysis to first unions (of women). This focus allows us to understand the relationship context when couples decide to move in together for the first time, as well as the outcomes in terms of the childbearing of such unions. The focus on first unions also allows us to understand how the age profile of cohabitants changes over time ${ }^{9}$.

Subsequently, we selected women who had had only one relationship and who were living with their partner at the time of the survey. This choice means that only $69 \%$ of all cohabitations in Latin America are included in the analysis and that this proportion of cohabiting unions ranges from $83 \%$ in Bolivia to $65 \%$ in Nicaragua. ${ }^{10}$

Consequently, the countries and final sample sizes used in this study (2000s) are Bolivia (2008, $\mathrm{n}=3,255)$, Brazil ${ }^{11}(2006, \mathrm{n}=2,887)$, Colombia $(2010, \mathrm{n}=12,627)$, Dominican Republic (2007, $\mathrm{n}=6,773)$, Guyana $(2009, \mathrm{n}=823)$, Honduras $(2005 / 6, \mathrm{n}=$ 4,732), Nicaragua (2001, $\mathrm{n}=2,589)$, and Peru $(2008, \mathrm{n}=4,372)$.

In order to document how the types of cohabitation have developed over the last decades, we used available information from previous DHS rounds of the 1980s and the 1990s. Included in the sample from the 1980s are Bolivia (1989, $\mathrm{n}=749)$, Brazil (1986, $\mathrm{n}=328)$, Colombia $(1986, \mathrm{n}=805)$, Dominican Republic $(1986, \mathrm{n}=1,775)$, and Peru $(1986, \mathrm{n}=736)$. The sample from the 1990s includes Bolivia $(1998, \mathrm{n}=1,026)$, Brazil $(1996, n=1,098)$, Colombia $(1995, n=2,072)$, Dominican Republic $(1996, n=1,984)$, and Peru $(1996, \mathrm{n}=6,393)$.

In order to avoid countries with larger sample sizes dominating the results we used equal size weighting of the samples.

\subsection{Variables}

To create a typology of cohabitation in Latin America we explored the observed variables that might indicate the different types. Firstly, we combined information on

\footnotetext{
${ }^{9}$ In order to check whether the exclusion of second- or higher-order unions affects our findings, the same analysis was performed with the full sample. The results are very similar (not shown, but available upon request) and indicate a similar profile of higher-order cohabitants. The main difference found was a higher number of children and women's older age profile in the sample including reconstituted families. Consequently, the focus on first unions does not interfere with our outcomes.

${ }^{10}$ Detailed information about the sample, i.e., the share of first- and higher-order cohabitations and the proportion of partnered women by marital status and country, is presented in Appendix 1.

${ }^{11}$ The Brazilian DHS is called Pesquisa Nacional de Demografia e Saúde (PNDS) and can be found here: http://bvsms.saude.gov.br/bvs/pnds/index.php
} 
age at start of cohabitation and age at birth of first child in order to identify women who had had a 'pre-cohabitation pregnancy', and included it as a binary variable in the model.

Next, we combined information on age at first union and type of first union to create an ordinal variable 'age at the start of cohabitation'. This classifies women who started to cohabit when they were (1) younger than 15 years old; (2) between 16 and 19 years old; (3) between 20 and 25 years old; or (4) older than 25 years. Then, as the variables (i) age at birth of first child and (ii) number of children are highly correlated, we combined this information to create the categorical variable "child - age at first child'. This indicator classifies women who, at the time of the survey, had (1) no children; (2) up to two children and the first child born when they were younger than 20 years old; (3) up to two children and the first child born when they were between 20 and 30 years old; (4) up to two children and the first child born when they were aged more than 30 years old; (5) more than two children and the first child born when they were younger than 20 years old; or (6) more than two children and the first child born when they were between 20 and 30 years old. No women respondents had more than two children and with the first child born when they were more than 30 years old.

Finally, three covariates are included in the analysis: 'education', which indicates women with (1) no education, (2) primary, (3) secondary, and (4) higher levels of education; 'age', which separates women (1) younger than 26 years old, (2) between 26 and 36 years old, and (3) older than 36 years; and household composition, which classifies (1) nuclear families composed of the couple and their children, (2) extended families, when other relatives also live in the household, and (3) composite families, when non-related people share the household with the family.

Listwise deletion was the method used for handling missing data. In our understanding the sample size of our data is large enough not to generate biased results due to the deletion of missing data. Descriptive statistics of all variables are included in Appendix 1 and support this supposition.

In Table 2 we summarize the variables and the expected outcomes of this study. In Table 2 our hypotheses are presented in the form of '+' and '-', which represent the direction of the expected effect of each observed variable (indicators) and covariate on the latent classes (traditional and modern cohabitation). 
Table 2: Variables and hypotheses

\begin{tabular}{|c|c|c|}
\hline Indicators & Traditional & Modern \\
\hline Pre-cohabitation pregnancy & + & - \\
\hline \multicolumn{3}{|l|}{ Age at the start of cohabitation } \\
\hline Younger than 15 years old & + & - \\
\hline Between 16 and 19 years old & + & - \\
\hline Between 20 and 25 years old & - & + \\
\hline Older than 25 years & - & + \\
\hline \multicolumn{3}{|l|}{ Children - Age at first child } \\
\hline No child & - & + \\
\hline 1 or 2 children, mother younger than 20 years old & + & - \\
\hline 1 or 2 children, mother between 20 and 30 years old & - & + \\
\hline Mother older than 30 years & - & + \\
\hline More than 2 children, mother younger than 20 years old & + & - \\
\hline More than 2 children, mother between 20 and 30 years old & + & - \\
\hline \multicolumn{3}{|l|}{ Covariates } \\
\hline \multicolumn{3}{|l|}{$\overline{\text { Age }}$} \\
\hline Younger than 26 years old & + & + \\
\hline Between 26 and 36 years old & + & + \\
\hline Older than 36 years & - & + \\
\hline \multicolumn{3}{|l|}{ Education } \\
\hline No education & + & - \\
\hline Primary & + & - \\
\hline Secondary & - & + \\
\hline Higher & - & + \\
\hline \multicolumn{3}{|l|}{ Household type } \\
\hline Extended & + & - \\
\hline Composite & + & - \\
\hline Nuclear & - & + \\
\hline
\end{tabular}

\subsection{Method}

To explore the different types of cohabitation in Latin America we conducted Multiple Group Latent Class Analysis (MGLCA). This technique identifies a latent typology that explains the interrelations between a set of observed indicators. The classification is considered to be latent because the variable is not observed directly (as in the case with types of cohabitation in this study). Relationships between observed indicators and the latent classes are studied in order to understand and characterize the nature of these latent types of cohabitation (McCutcheon 1987). 
Considering the heterogeneity of Latin American countries in terms of colonization history, socioeconomic development, and spoken language, it must be demonstrated that the latent concept of 'type of cohabitation' and its indicators have been measured in an equivalent or invariant way. The definition of invariance deals with similarities in the way in which latent concepts are interpreted among different cultures or cultural groups. It "implies that a concept can be meaningfully discussed in the cultures or cultural groups concerned" (Billiet and Welkenhuysen-Gybels 2004, p. 3). Consequently, comparisons between groups are not reliable without first assessing whether the concepts used are in fact comparable (e.g., Billiet and WelkenhuysenGybels 2004; Billiet 2003).

Detailed information about Latent Class Analysis and Multiple Group Latent Class Analysis as a strategy to attest measurement invariance can be found in Appendix 2.

\section{Results}

First, as the expectation is that more than one type of cohabitation will be found, we contrast the goodness of $\mathrm{fit}^{12}$ of a model with one latent class against the models with more latent classes for three DHS rounds: the 1980s, 1990s, and 2000s. Separate analyses of each Latin American country and sample show three different types of cohabitation emerging from the data. ${ }^{13}$ Consequently we proceeded with the MGLCA. The measurement invariance results are very similar for the three DHS rounds. For the sake of brevity we decided to focus on the results for the most recent data, the 2000s.

Latent Class Analysis is conducted with the pooled country samples to verify whether, again, a structure of three classes emerges from the data. Because of our extremely large sample it is not advisable to use BIC as an absolute criterion to determine the number of classes. It is an expected phenomenon that within large datasets, fit indices continue to improve (even BIC) when adding classes, leading to uninterpretable solutions. For this reason we chose to evaluate the necessity of adding a latent class by looking at the drop in BIC (see Figure 1) as well as the interpretability of the solution. If the additional classes only cause a very small drop in BIC or account for a very small proportion of women, we favor a solution with fewer classes.

\footnotetext{
${ }^{12}$ Because of the large sample sizes we use the BIC as the model selection criterion, which penalizes for sample size (for more details see McCutcheon (2002)).

${ }^{13}$ Separate results for each country and sample are available upon request.
} 


\section{Figure 1: Drop in BIC in Latent Class Analysis for sampled data of eight Latin American countries (2000s)}

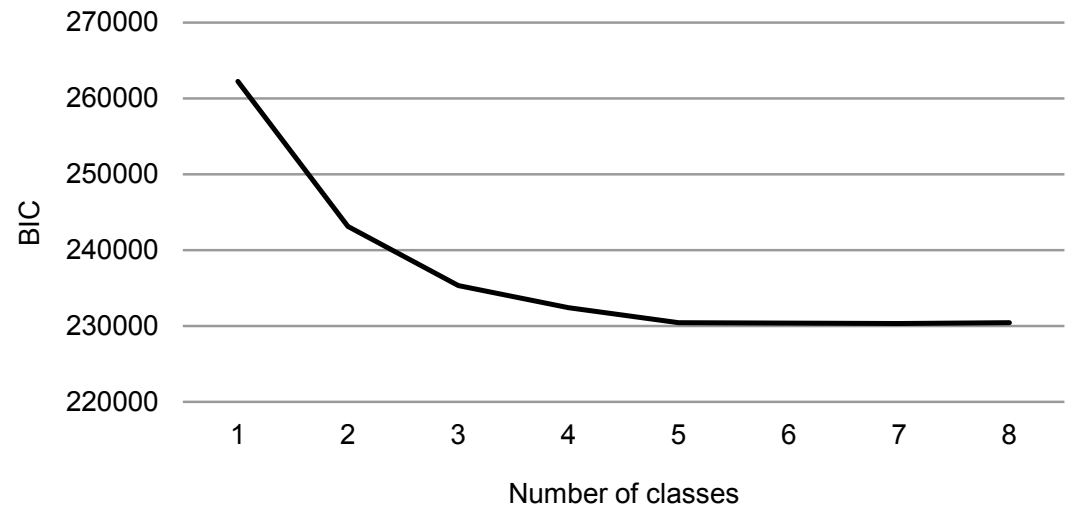

Figure 1 shows that the drop in the BIC starts to level off from the three classes model. In verifying the class profiles, from a substantive point of view we recognize that the model with three clusters has a broader difference between classes (representing $48 \%, 32 \%$, and $20 \%$ of the total sample, respectively). For the model with four classes, the first class does not change when compared with the previous model (it remains at $48 \%$ ); the second and third classes show a change in their representation, at $27 \%$ and $18 \%$, respectively, and the fourth class represents only $7 \%$ of our sample. The fourth class also does not differ substantively from the third and second classes; thus it does not add any theoretical relevance. Therefore we decided to continue using the MGLCA with the model with three classes.

The level of measurement equivalence in the data is specified by the degree of homogeneity in the model with a better goodness of fit, namely a smaller BIC. In consonance with Kankaras et al. (2011) we first tested for measurement invariance (1); next, we verified whether each item is also invariant (2a and $2 b$ ); and finally we assessed the effect of age, educational level, and household type on Latin American types of cohabitation ( $3 a, 3 b$ and $3 c$ ). Table 3 presents the goodness of fit for the various MGLCA that are estimated.

As presented in Table 3 (1), the partially homogeneous model fits the data best ( $\mathrm{BIC}=-94,897.3$ ). This implies that the relationship between observed indicators and latent classes (i.e., slopes) are invariant over countries, while the intercepts are not. In other words, the values of the conditional response probabilities are different across countries, but the relationship between the latent type of cohabitation and the observed indicators are the same, which guarantees cross-country comparability (Kankaras et al. 2011). 
Table 3: Goodness of fit of the Three Latent Classes Models (2000s)

\begin{tabular}{|c|c|c|c|c|c|}
\hline Test & Model & LL & BIC & Npar & Df \\
\hline$\overline{(1)}$ & Complete Heterogeneity & -154694.5 & 311382.8 & 193 & 183 \\
\hline Measurement & Partial Homogeneity & -94897.3 & 190703.7 & 88 & 288 \\
\hline Invariance & Structural Homogeneity & -95831.0 & 192064.8 & 39 & 337 \\
\hline \multirow{2}{*}{$\begin{array}{l}\text { (2a) Item-level } \\
\text { analysis: }\end{array}$} & Partial Homogeneity & -94897.3 & 190703.7 & 88 & 288 \\
\hline & Pre-cohabitation pregnancy & -97317.2 & 195522.9 & 86 & 290 \\
\hline \multirow{2}{*}{$\begin{array}{l}\text { Intercept } \\
\text { invariant }\end{array}$} & Age at first cohabitation & -104516.7 & 209921.8 & 86 & 290 \\
\hline & Number of children and age at first child & -105156.6 & 211119.1 & 78 & 298 \\
\hline \multirow{4}{*}{$\begin{array}{l}\text { (2b) Item-level } \\
\text { analysis: Slope } \\
\text { invariant }\end{array}$} & Partial Homogeneity & -94897.3 & 190703.7 & 88 & 288 \\
\hline & Pre-cohabitation pregnancy & -98326.9 & 197470.0 & 79 & 297 \\
\hline & Age at first cohabitation & -105543.0 & 211902.2 & 79 & 297 \\
\hline & Number of children and age at first child & -105715.9 & 211876.0 & 43 & 333 \\
\hline \multirow{3}{*}{$\begin{array}{l}\text { (3a) Covariate: } \\
\text { Age }\end{array}$} & Partial Homogeneity & -94897.3 & 190703.7 & 88 & 288 \\
\hline & Age on Classes & -92267.4 & 185464.7 & 90 & 1038 \\
\hline & Age on Classes and Indicators & -86968.5 & 174939.1 & 97 & 1031 \\
\hline \multirow{3}{*}{$\begin{array}{l}\text { (3b) Covariate: } \\
\text { Education }\end{array}$} & Age on Classes and Indicators & -86968.5 & 174939.1 & 97 & 1031 \\
\hline & $\begin{array}{l}\text { Age on Classes and Indicators and } \\
\text { Education on Classes }\end{array}$ & -85653.4 & 172329.5 & 99 & 4413 \\
\hline & $\begin{array}{l}\text { Age and Education on Classes and } \\
\text { Indicators }\end{array}$ & -84625.2 & 170345.5 & 106 & 4406 \\
\hline \multirow{3}{*}{$\begin{array}{l}\text { (3c) Covariate: } \\
\text { Type of Family }\end{array}$} & $\begin{array}{l}\text { Age and Education on Classes and } \\
\text { Indicators }\end{array}$ & -84625.2 & 170345.5 & 106 & 4406 \\
\hline & $\begin{array}{l}\text { Age and Education on Classes and } \\
\text { Indicators and Type of family on Classes }\end{array}$ & -84610.3 & 170418.9 & 116 & 17462 \\
\hline & $\begin{array}{l}\text { Age, Education and Type of family on } \\
\text { Classes and Indicators }\end{array}$ & -84411.2 & 170382.5 & 151 & 17427 \\
\hline
\end{tabular}

Note: LL: Log-likelihood; BIC: Bayesian information criterion; Npar: number of parameters; df: degrees of freedom.

In order to gain better insight as to whether one of the observed indicators is a source of invariance, we performed an item-level analysis. This is shown in sections 2a and $2 \mathrm{~b}$ of Table 3 , in terms of invariance in both intercept and slope parameters. In 2a, invariance in the intercept is shown, which means that the direct effect from the latent variable to the indicator (e.g., the effect of types of cohabitation on age at start of cohabitation) is excluded from the analysis. Next, $2 b$ attests to slope invariance, meaning that the indirect effect of the latent variable on the indicator through country (the interaction between country and the indicator) was removed from the equation. The goodness of fit of both models, without interaction or direct effects, is worse than that 
found in the partially homogeneous model. This indicates that the source of invariance is not situated at the item level. This evidence suggests that differences within Latin American types of cohabitations are one feature of cohabitation found throughout all of the countries investigated.

Next, in order to verify whether types of cohabitation in Latin America differ according to the age group of the respondent at the time of data collection, educational level, and household type, we included 'age', 'education' and 'household type' as covariates in our model (sections $3 \mathrm{a}, 3 \mathrm{~b}$ and $3 \mathrm{c}$ in Table 3). Comparing the goodness of fit of the partially homogeneous model to the model (3a) in which age has a direct effect on the types of cohabitation (classes), and also to the model in which age has a direct and also an indirect effect through the observed indicators on the types of cohabitation, one can see that the latter model better exemplifies the data. Similarly, the inclusion of a direct and an indirect effect of education (3b) on the indicators and on the types of cohabitation improves the goodness of fit of our model. However, neither the inclusion of a direct effect nor an indirect effect of the variable 'household type' (3c) improved the goodness of fit of our model. As a consequence, the model shown in Table 3, section $3 \mathrm{~b}$ is the one that best fits the data. The variable 'household type' does not improve the model's goodness of fit and is not included in the final analysis.

These results attest that both indicators and cohabitation profiles differ according to the age and the educational level of the respondent at the time of the DHS interview, but not to their household type. The inclusion of the direct effect of age at the time of the DHS interview on each type of cohabitation combined with the indirect effect of this variable controls for two potential limitations of our analysis: first, the combination of data on the age when moving in together and the age at the time of the survey controls for the length of the cohabitation; and, second, the inclusion of the indirect effect of age of the woman at data collection on each indicator of class membership (observed variables) controls for the different degrees of exposure to the risk of fertility, getting married, and union dissolution related to the age of the respondent.

After identifying the types of cohabitation in Latin America and attesting their comparison over countries, the next two steps refer to a substantive interpretation of the different types of cohabitation and the comparison of class sizes across countries. First, the response probabilities ${ }^{14}$ obtained for the better goodness of fit model (3b) for DHS data from the 2000 s is shown in Table $4^{15}$.

\footnotetext{
${ }^{14}$ Conditional response probabilities or response probabilities indicate how likely it is that a category of one observed variable is reported by the members of the different classes. As such, they designate the strength of the association between the latent classes and the indicators (for more information, see Appendix 2).

${ }^{15}$ The table with item response and types of cohabitation probability for the 1980s and the 1990s are included in Appendix 3.
} 
Table 4: Item response and types of cohabitation probability (2000s)

\begin{tabular}{|c|c|c|c|}
\hline \multirow{2}{*}{ Response probabilities } & \multicolumn{3}{|c|}{ 2000s } \\
\hline & Class 1 & Class 2 & Class 3 \\
\hline \multicolumn{4}{|l|}{ Pre-cohabitation pregnancy } \\
\hline No & 0.78 & 1.00 & 0.00 \\
\hline Yes & 0.22 & 0.00 & 1.00 \\
\hline \multicolumn{4}{|l|}{ Age at the start of cohabitation } \\
\hline Younger than 15 years old & 0.42 & 0.00 & 0.00 \\
\hline Between 16 and 19 years old & 0.58 & 0.17 & 0.06 \\
\hline Between 20 and 25 years old & 0.01 & 0.69 & 0.62 \\
\hline Older than 25 years & 0.00 & 0.14 & 0.32 \\
\hline \multicolumn{4}{|l|}{ Children - Age at first child } \\
\hline No child & 0.06 & 0.22 & 0.00 \\
\hline 1 or 2 children, mother younger than 20 years old & 0.44 & 0.00 & 0.20 \\
\hline 1 or 2 children, mother between 20 and 30 years old & 0.02 & 0.47 & 0.35 \\
\hline Mother older than 30 years & 0.00 & 0.06 & 0.03 \\
\hline More than 2 children, mother younger than 20 years old & 0.46 & 0.00 & 0.20 \\
\hline More than 2 children, mother between 20 and 30 years old & 0.02 & 0.25 & 0.22 \\
\hline
\end{tabular}

\section{Age}

Younger than 26 years old

Between 26 and 36 years old

0.51

0.33

0.23

Older than 36 years

$\begin{array}{lll}0.30 & 0.40 \quad 0.45\end{array}$

$\begin{array}{lll}0.18 & 0.28 & 0.31\end{array}$

Education

No education

$\begin{array}{lll}0.09 & 0.04 & 0.05\end{array}$

Primary

$\begin{array}{lll}0.53 & 0.34 & 0.33\end{array}$

Secondary

$\begin{array}{lll}0.35 & 0.46 \quad 0.47\end{array}$

Higher

0.02

0.16

0.15

\begin{tabular}{llll}
\hline Latent class proportions & & & \\
\hline Latin America & 0.48 & 0.32 & 0.20 \\
Brazil & 0.36 & 0.43 & 0.21 \\
Bolivia & 0.40 & 0.30 & 0.30 \\
Colombia & 0.36 & 0.33 & 0.31 \\
Dominican Republic & 0.52 & 0.38 & 0.10 \\
Honduras & 0.57 & 0.33 & 0.10 \\
Nicaragua & 0.62 & 0.30 & 0.07 \\
Guyana & 0.38 & 0.31 & 0.30 \\
Peru & 0.35 & 0.35 & 0.31 \\
\hline
\end{tabular}

Note: Entries are class profiles for MGLCA 
The first class or type of cohabitation starts to cohabit at very young ages. Practically all women in this class start to cohabit before they are 20 years old (99\%) and, $42 \%$ of them moved in together when they were younger than 15 years old. $22 \%$ were pregnant or had a child before the start of cohabitation. Most of them $(90 \%)$ have their first child before they are 20 years old and almost half of them had more than two children at the time of the survey.

The second type of cohabitation groups women who start to cohabit in their twenties. None of them experienced single pregnancy. Women in this second class tend to have lower fertility: $22 \%$ do not have any children and half of them have only one or two children. The third type of cohabitation groups women who start to cohabit at somewhat older ages. Most of them (62\%) are aged between 20 and 25 years old when they move in together and $32 \%$ were older than 25 years. Women in the third class all became pregnant before they started to cohabit ${ }^{16}, 36 \%$ of them had children in their twenties, and none of these women were childless at the time of the survey.

Looking at the covariates, it can be seen that the first group of cohabitants includes predominantly younger and lower-educated women. Half of them $(51 \%)$ are younger than 26 years old and $62 \%$ had completed up to primary education at the time of the survey. The second group comprises women of all ages and with higher educational profiles. The third group is characterized by older women with the same education level as women in the second class.

Comparing these results to our proposed outcomes, we can say that we have found one traditional and two modern types of cohabitation in Latin America. The 'traditional' type is represented by class 1 . The striking feature of this type of cohabitation is the early age at which these women start to cohabit. They do not always start cohabitation immediately following their first pregnancy, but deliver their first child at a young age and then have more children. Only $20 \%$ of them are older than 30 years, so this type of cohabitation is more visible among younger cohorts.

We labeled class 2 the 'innovative' type of cohabitation. This group of women starts to cohabit in early adulthood without experiencing single pregnancy. They are older when they have their first child, and have fewer children. This is the highereducated group, where $16 \%$ of women have participated in or completed some level of higher education. The innovative type of consensual union is present at all ages, demonstrating that it is not a recent phenomenon in Latin America.

\footnotetext{
${ }^{16}$ It is interesting to note that while all innovative cohabiters started their unions without experiencing precohabitation pregnancy, all blended cohabitants started their unions after pregnancy or childbearing. Although such a perfect match is very unusual in the statistical models, it seems to be the case for the different types of cohabitation in Latin America. The parameters and the factor loadings between the observed variable (precohabitation pregnancy) and the latent classes (types of cohabitation) are significant at the 0.001 level and the $\mathrm{R}^{2}$ of the equation is 0.63 . In addition, having verified models with more than three classes, we realize that the same match appears in all models from 3 to 8 classes.
} 
The third class was labeled 'blended' cohabitation. This type of union shares similar characteristics with both the traditional and the innovative type of cohabitation. Women in the blended type of cohabitation start to cohabit at an older age and have a similar level of education to the women in the innovative type of cohabitation. Nevertheless, all of the women in this class became pregnant before the start of their cohabitation. They also share similar fertility histories with women in the traditional type of cohabitation, being younger when delivering their first child and having more children. Considering that we do not have information on the timing of education, we do not know the level of education of women living in the blended type of cohabitation at the time of becoming pregnant and/or starting to cohabit. However, we do know that these women had attained higher levels of education at the time of the survey and we also know that they were still living in a consensual union. Thus, we cannot say if this cohabitation started as a traditional or a modern type of cohabitation, but our results show that it became similar to the modern types of cohabitation, as a kind of alternative to a marriage relationship.

Turning now to the comparison of latent class proportions, it is possible to identify two groups of Latin American countries. The first group is composed of South American countries: Brazil, Bolivia, Colombia, Guyana, and Peru. In this group 35\% $40 \%$ of the sample belong to the class of traditional cohabitation, $21 \%-31 \%$ belong to the class of blended cohabiters, and the remaining $30 \%-43 \%$ belong to the class of innovative cohabitations (according to country). The second group of countries is formed of Central American countries (Honduras and Nicaragua) and the Caribbean Dominican Republic. In these countries most of the women $(52 \%-62 \%)$ can be classified within traditional cohabitation, while only $7 \%-10 \%$ are classified as blended and $30 \%-38 \%$ are classified as innovative cohabitants.

These results support previous evidence about the heterogeneity of the incidence of cohabitation in Latin America. Caribbean (Dominican Republic) and Central American (Honduras and Nicaragua) countries present the highest share of traditional cohabitation in the region. This is probably related to the maintenance of the historical incidence of this type of cohabitation in these regions. Furthermore, while the blended type of cohabitation has increased more in most of the analyzed countries, the innovative type of cohabitation was the consensual union, which developed more in South American countries, especially Brazil.

Brazil is the Latin American country in this study that has experienced the sharpest increase in cohabitation over time. The increase of cohabitation in Brazil is comparable to that observed in the countries from the Southern Cone, specifically Argentina, Uruguay, and Chile. These countries were not included in the typology of cohabitation in Latin America due to lack of data, but they have visible socioeconomic similarities with Brazil. Consequently, looking at previous evidence about the rise of cohabitation 
in these countries (e.g., Binstock and Cabella 2011; Quilodrán-Salgado 2011) and the results found for Brazil, higher levels of the innovative type of cohabitation could be expected in the Southern Cone as well.

We finally turn to the comparison of the types of cohabitation over time. Figure 2 compares the response probabilities of the observed indicators of three types of cohabitation for the DHS samples of the 1980s, 1990s, and 2000s.

Figure 2: Response probabilities of indicators of types of cohabitation in Latin America (1980s, 1990s, and 2000s)

Pre-cohabitation pregnancy

$\varpi$ No $\approx$ Yes

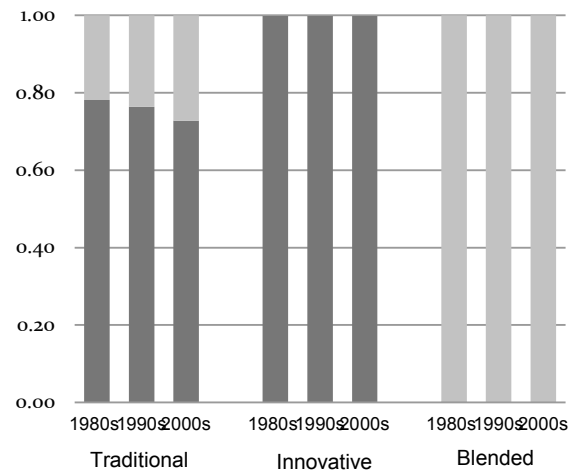

Age at the start of cohabitation

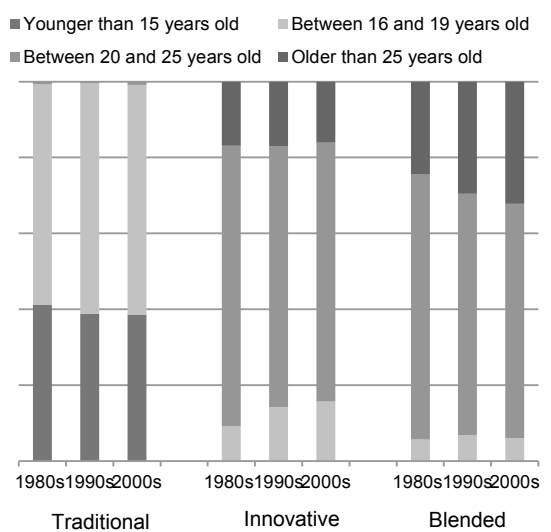

Children - Age at first child

- No child

- 1 or 2 children, mother between 20 and 30 years old

More than 2 children, mother younger than 20 years old
1 or 2 children, mother younger than 20 years old - Mother older than 30 years

More than 2 children, mother between 20 and 30 years old

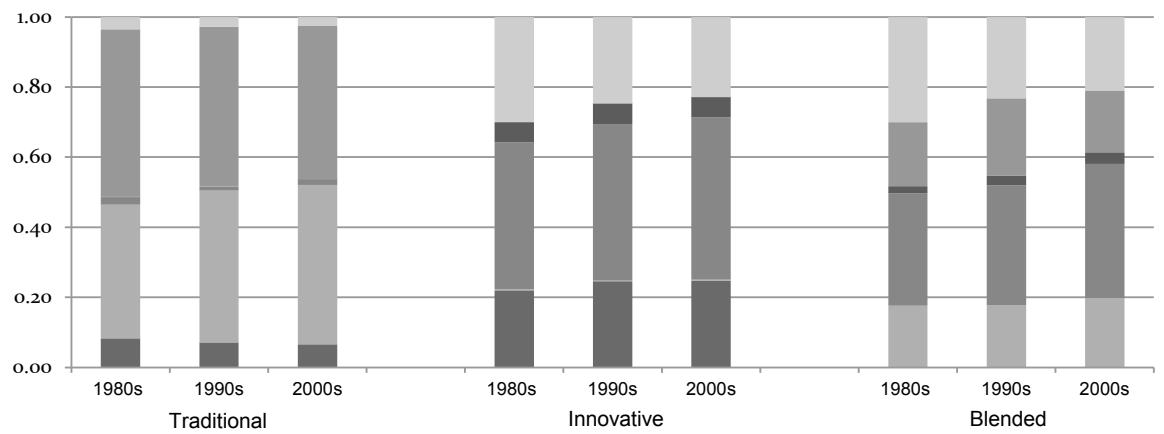


Looking at the response probabilities of the observed indicators of different types of cohabitation it can be seen that the relationship context at the beginning of cohabitation and the outcomes in terms of childbearing are quite similar for the three types of cohabitation over time. Data from the three DHS rounds under analysis show that, at least since the $1980 \mathrm{~s}$, women in traditional cohabitation have approximately $22 \%$ probability of moving in with their partner after pregnancy or childbearing. They cohabit at very young ages and have more children at younger ages than women in the remaining classes. In addition, since the 1980s innovative cohabiters have started to cohabit after their twenties without experiencing pregnancy or childbearing, and have fewer children at older ages. Blended cohabiters present a similar profile, starting to cohabit after the age of 20 (an increasing number of women in this class start their cohabitation when they are older than 25 years old) and have fewer children later in their life. As stated previously, women from this group always start to cohabit after a pregnancy or childbearing.

Figure 3 illustrates the evolution of the correlation between age at the time of the survey and the educational profile of cohabitants with the different types of cohabitation over time in Latin America.

\section{Figure 3: Age at the time of the survey and the educational profile of} cohabitants over time (1980s, 1990s, 2000s)

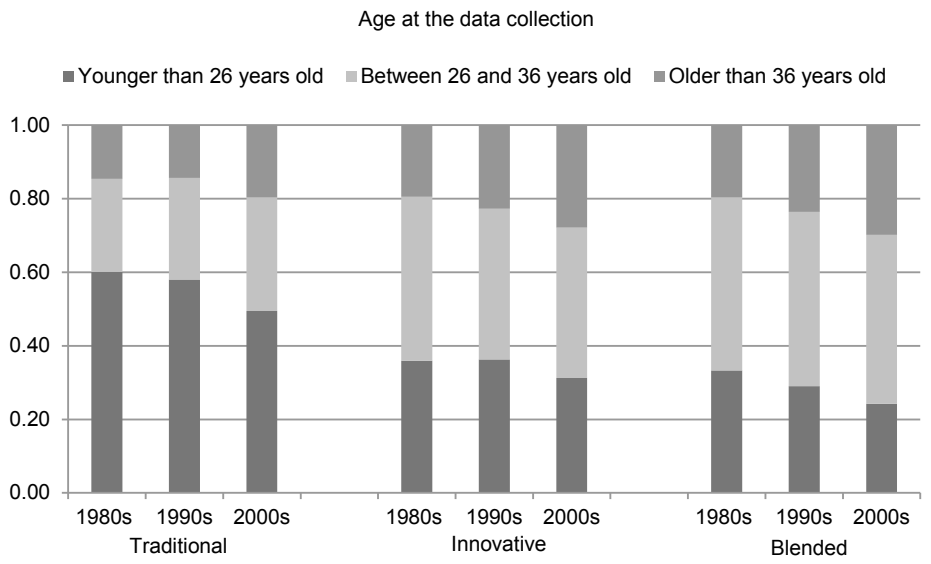




\section{Figure 3: (Continued)}

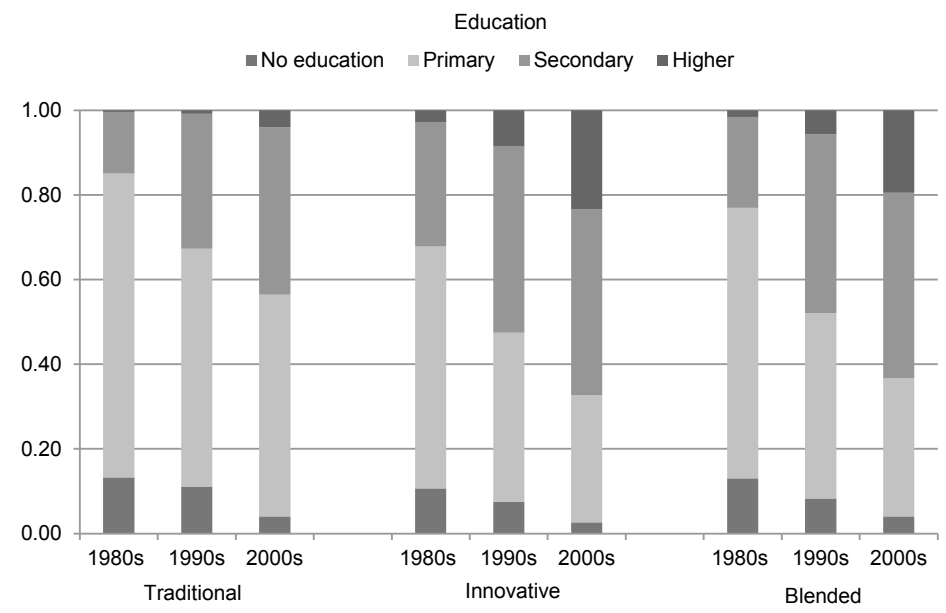

A noticeable change over time is evident when the analysis turns to the covariates, age and education. While in the $1980 \mathrm{~s} 15 \%, 19 \%$, and $20 \%$ of cohabiters who were older than 36 years old at the time of the survey were still living in the traditional, innovative, and blended types of cohabitation, respectively, the figures for the same age-group for the $2000 \mathrm{~s}$ are $18 \%, 28 \%$, and $31 \%$. This means that although the age profile of traditional cohabitants is fairly constant over time, older women are becoming more likely to be found living in one of the modern types of cohabitation.

There is also a visible change in the educational profile of women in cohabiting unions. The proportion of lower-educated women (no education and primary) in consensual unions has decreased for all types of cohabitation, while the percentage of women with secondary education has increased over time. This is plausibly related to the expansion of education in the region. Interestingly, even though the proportion of higher-educated women in traditional cohabitation is almost constant over time, the proportions of the higher educated in the innovative and blended types has jumped from $3 \%$ and $2 \%$ in the 1980 s to $16 \%$ and $15 \%$ in the 2000 s.

Finally, Figure 4 compares the evolution of the incidence of types of cohabitation in different Latin American countries over time. 
Figure 4: Incidence of types of cohabitation in different Latin American countries over time (1980s, 1990s, 2000s)
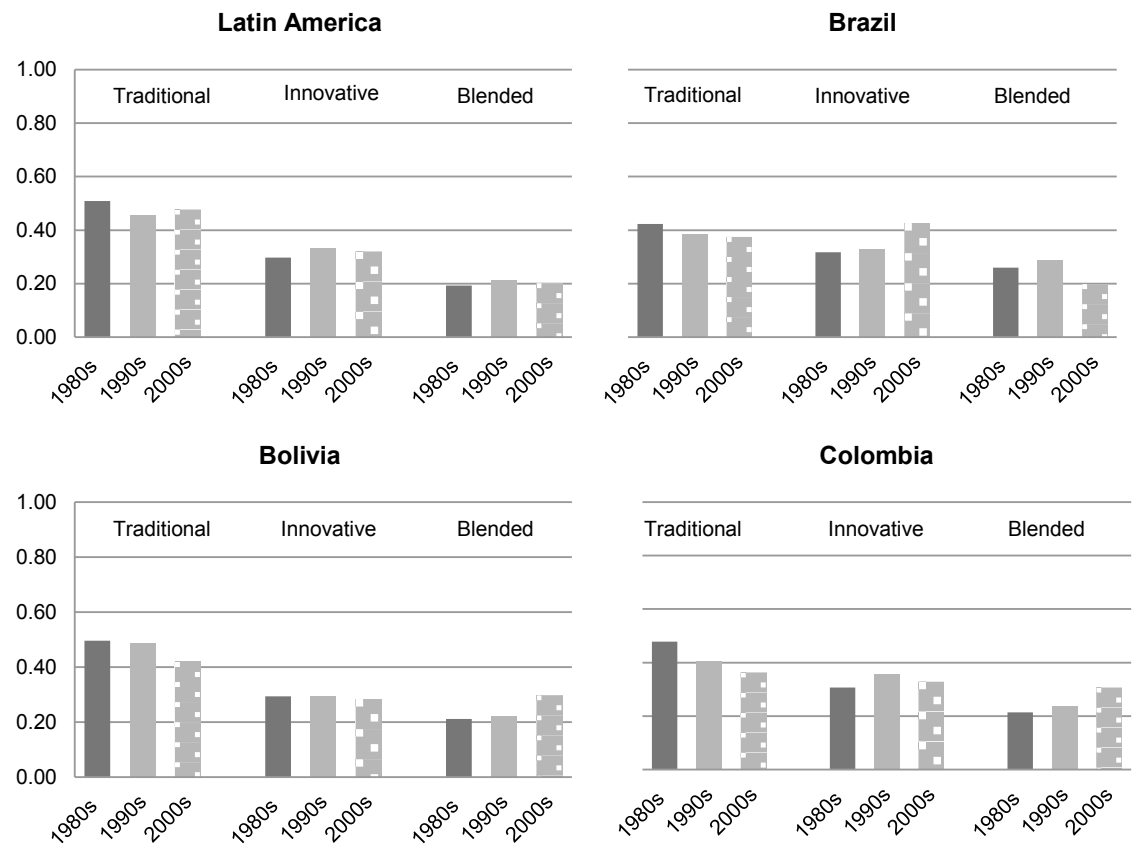

Dominican Republic
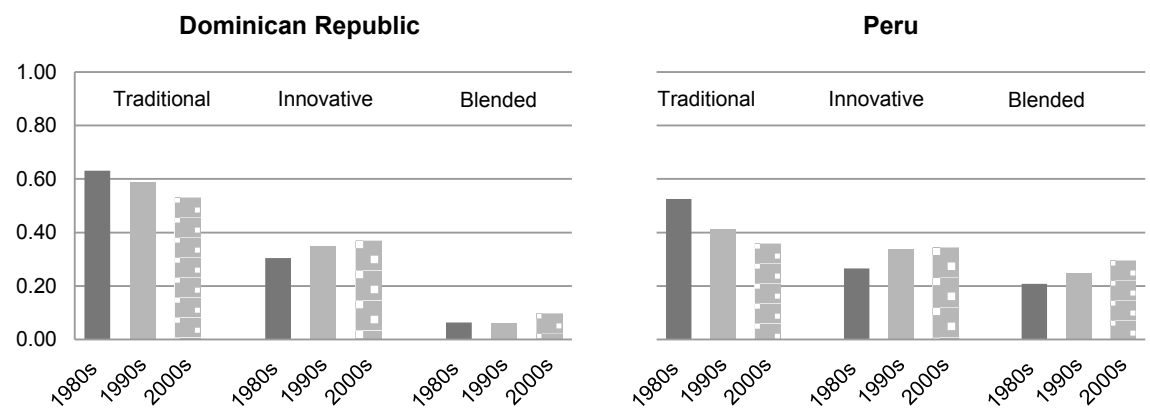

From Figure 4 we can discern that in most countries the proportion of people living in one of the modern types of cohabitation is increasing over time, although changes in the traditional type are less evident. In order to verify if these changes in the proportions of women living in each type of cohabitation over time are statistically 
significant, we performed a $\mathrm{Chi}^{2}$ independency test for different populations, comparing the samples of the 1980s to the 2000s for each country and type of cohabitation. The results are presented in Table 5, and show that the differences between the periods are significant for all countries under analysis, but not for all types of cohabitation.

Table 5: $\quad \mathrm{Chi}^{2}$ independency test $(1980 \mathrm{~s}-2000 \mathrm{~s})$

\begin{tabular}{|c|c|c|c|c|}
\hline Country & Chi-Square & df & p-value & Significant \\
\hline Bolivia & 14.929 & 2 & $<0.0001$ & $* * *$ \\
\hline Blended & 7.170 & 1 & 0.007 & $* * *$ \\
\hline Innovative & 4.830 & 1 & 0.028 & $* *$ \\
\hline Traditional & 0.134 & 1 & 0.7143 & \\
\hline Brazil & 16.839 & 2 & $<0.0001$ & $* * *$ \\
\hline Blended & 1.167 & 1 & 0.280 & \\
\hline Innovative & 5.808 & 1 & 0.016 & $* *$ \\
\hline Traditional & 8.147 & 1 & 0.004 & $* * *$ \\
\hline Colombia & 14.244 & 2 & $<0.0001$ & $* * *$ \\
\hline Blended & 5.628 & 1 & 0.0177 & $* *$ \\
\hline Innovative & 0.345 & 1 & 0.557 & \\
\hline Traditional & 7.417 & 1 & 0.006 & $* * *$ \\
\hline Dominican Republic & 804.033 & 2 & $<0.0001$ & $* * *$ \\
\hline Blended & 538.850 & 1 & $<0.0001$ & $* * *$ \\
\hline Innovative & 86.120 & 1 & $<0.0001$ & $* * *$ \\
\hline Traditional & 27.929 & 1 & $<0.0001$ & $* * *$ \\
\hline Peru & 29.723 & 2 & $<0.0001$ & $* * *$ \\
\hline Blended & 0.187 & 1 & 0.665 & \\
\hline Innovative & 14.730 & 1 & 0.0001 & $* * *$ \\
\hline Traditional & 10.529 & 1 & 0.001 & $* * *$ \\
\hline
\end{tabular}

We now turn to Figure 4. The comparison of contemporary results with those from available previous DHS rounds shows an overall although often modest decrease in the traditional type of cohabitation, combined with a general increase in the proportion of women in at least one of the modern types of cohabitation over time. The reduction in the proportion of women living in the traditional type of cohabitation is shown for 
almost all countries, with the exception of Bolivia, where this change is not statistically significant. In the remaining countries the change in the proportion of women living in the traditional type of cohabitation is significant and ranges from 5\% in Brazil to $17 \%$ in Peru.

In regard to the modern types of cohabitation, some countries experienced an increase in the innovative type while others demonstrate that the blended type is on the rise. Whereas Brazil shows a significant increase of $11 \%$ in the innovative type of cohabitation, the blended type had $10 \%$ growth in Colombia and $9 \%$ in Bolivia. Changes in the incidence of the innovative type in Colombia and in the blended type in Peru and Brazil are not statistically significant. The results for the Dominican Republic show a slight increase in both types of modern cohabitation: $6 \%$ for innovative and $4 \%$ for blended cohabitation. In sum, among the modern types of cohabitation, Brazil is the Latin American country in which the innovative type is most evident, accounting for $43 \%$ of all types of cohabitation in the country. The blended type has a higher incidence in the remaining Latin American countries.

These results refer to the proportions of each type of cohabitation over time. In this sense the amount of couples living in the traditional type of cohabitation can be higher in comparison to previous years if the overall incidence of cohabitation increases.

\section{Conclusion}

Historical, socioeconomic, and cultural roots make consensual unions an intriguing feature of nuptiality in Latin America. It is suggested that modernity combined with recent socioeconomic development and existent social inequalities lead to the coexistence of different types of cohabitation in this region: traditional and modern.

This study used three rounds of Demographic and Heath Survey data to differentiate the types of cohabitation in Latin America and to document the evolution of these types of cohabitation over time. Our results point to a persistence, though with a general decrease, of the traditional type of cohabitation across the countries: half of the women in the most recent sample who started to cohabit at a younger age (often as adolescents) are traditional cohabiters and experience high fertility at a young age. It is possible that these women are under social or economic pressure. Although cohabitation is not always a strategy to cope with single pregnancy, starting a new family can be seen as a means to handle other types of problem, such as extreme poverty or the need to take care of household work and younger brothers and sisters (Arriagada 2002).

Two modern types of cohabitation are on the rise in Latin America. These modern types of consensual union are present in all the countries under analysis and represent 
between $34 \%$ and $64 \%$ of those women whose family formation started by way of cohabitation. While the innovative type of cohabitation shows features similar to those of the cohabitation observed among higher-educated people in developed countries, the blended type of cohabitation gives the impression of being a more complex type of consensual union. It shares features similar to both the traditional form of cohabitation (i.e., pre-cohabitation pregnancy) and the innovative form of cohabitation (i.e., later union formation and higher level of education). It is not possible to say whether this type of cohabitation started as a traditional or modern type of consensual union. However, we can interpret it as a 'transitional' type of cohabitation, with some modern features at the time of data collection. In this sense, both modern types of cohabitation have characteristics that are consistent with the pattern described by the SDT theory, in the sense that these modern types of cohabitation group higher-educated women with lower fertility that started to cohabit later in life.

Similar to the cohabitation found in developed countries, Latin American cohabitation is chosen by a very heterogeneous group (Bumpass et al. 1991; Hiekel et al. 2012; Sobotka and Toulemon 2008). In the traditional type of cohabitation women move in with their partners at very young ages. This type of union is found among the lower-educated groups with higher fertility and it is probably a strategy to cope with economic hardship. There is also some heterogeneity between the modern types of cohabitation. While the innovative type can represent a trial period before marriage or an alternative to singlehood, couples in the blended type are probably cohabiting as an alternative to marriage.

The same analysis was conducted with earlier DHS data (1980s and 1990s) with the aim of analyzing the evolution of the different types of cohabitation in the region. It was shown that traditional cohabitation is giving way to the modern types of cohabitation. In addition, while age at the time of the survey and the educational profile of traditional cohabitants are quite stable over time, the ages of women living in the modern types of cohabitation are increasing and the women are also higher-educated. Considering that our sample is limited to first unions, and that the average age at start of cohabitation is quite constant in these types of cohabitation over time, it is possible that these unions are lasting longer. However, the cross sectional nature of our data does not allow us to examine this assumption. At this point it is only possible to indicate an older and more mature profile for women in the modern types of cohabitation in Latin America in comparison to the traditional ones.

Also, the distribution of different types of cohabitation across Latin American countries reflects the regional heterogeneity in terms of nuptiality patterns. Central American and Caribbean countries show the highest share of traditional cohabitation in comparison to South American countries. While the greatest increase in the majority of the countries was in blended cohabitation, innovative cohabitation was the type of 
consensual union more developed in Brazil. As stated before, Brazil is the analyzed Latin American country that has experienced the sharpest growth in cohabitation over time, comparable to that observed in the countries from the Southern Cone - Argentina, Chile, and Uruguay (Esteve at al. 2013). Therefore, considering previous evidence about the rise of cohabitation in these countries (e.g., Binstock and Cabella 2011; Quilodrán-Salgado 2011) and our results for Brazil, higher levels of the innovative type of cohabitation could be expected in the Southern Cone as well.

The results presented in this study are in line with previous theoretical arguments and give additional evidence that the cohabitation boom in Latin America is related to the increasing empowerment of certain groups of women. However, at the same time women's social exclusion in the region ensures that traditional types of cohabitation persist. While the modern types of cohabitation are practiced by older, higher-educated women with lower fertility, the traditional type starts very early in the life course and is practiced by lower-educated women with high fertility at young ages.

The identification of these types of consensual union can help the development of efficient public policies aimed at protecting partners and children. Considering that the institutional protection required for couples living in the traditional form of consensual union is different from the protection required by couples living in the modern types, the information provided in this study can be used to develop targeted interventions aimed at these different groups of cohabiters. For example, according to our results almost $50 \%$ of female cohabitants in Latin America are women who form a family and have children before they are able to complete, their secondary education. In this sense public policies are needed to assist these women and their families. In addition, childbearing is related to all three identified types of cohabitation, so children's rights should not be connected to marriage.

A number of important limitations to this study must be acknowledged. First, these findings are limited by the use of a cross-sectional design, which restricts which specific research questions can be addressed. For instance, the absence of (at least) retrospective information on education limits the interpretation of the blended type of cohabitation, as we do not know when women in this type of cohabitation completed their education. Second, the absence of retrospective data also does not allow us to assess the stability of these consensual unions. Third, information for the younger cohorts is incomplete, in the sense that they are still at an early stage of their life trajectories. For instance, they have had less time and opportunity to get married and to have children. The inclusion of an interaction effect between age at the time of the survey and each indicator helps to minimize the problems caused by this data limitation. However, it is important to keep in mind that the number of children in each type of cohabitation can increase with time due to the well-known higher fertility of cohabiting unions in Latin America or to the postponement ingredient of the SDT. Finally, another 
important drawback is the absence of information on the values and attitudes of cohabiters, such as religious (secular) values or the meaning given to cohabitation, which could enrich this typology enormously.

This research has opened the way to new research questions regarding cohabitation in Latin America. Supplementary work could be done to establish the factors related to the transition to one type of cohabitation or another. Furthermore, the meanings of the different types of cohabitation (and marriage) to couples living in these different arrangements should be analyzed in depth in future research. The analysis of the meaning given to cohabitation as well as the transitions made by these couples would improve the understanding of the causes and effects of cohabitation in different Latin American social groups.

To conclude, marriage and its meanings and forms should also be included in the analysis. Marriage rates have declined in Latin America but the prevalence of men and women in unions (regardless of type) has remained quite constant over the years. This suggests that as marriage is declining, cohabitation is increasing at similar rate. As suggested by Kiernan $(2001,2004)$ and Prinz $(1995)$, the meaning given to cohabitation by cohabitants, e.g., a trial period before marriage or an alternative or substitute to it, depends on the value that couples or social groups give to marriage as a social institution. Following this reasoning, it is important to examine the strength of marriage as an institution in the region and to identify who is taking advantage of its institutional protection. 


\section{References}

Arriagada, I. (2002). Changes and inequality in Latin American families. Cepal Review 77: $135-153$.

Billiet, J. (2003). Cross-Cultural Equivalence with Structural Equation Modeling. In: Harkness J.A., van de Vijver F.J.R., and Mohler P.P. (Eds.). Cross-Cultural Survey Methods. Hoboken, New Jersey: John Wiley and Sons: 247-264.

Billiet, J. and Welkenhuysen-Gybels, J. (2004). Assessing cross-national construct equivalence in the ESS: the case of six immigration items. In: van Dijkum C., Blasius J., and Durand C. (Eds.). RC33 Sixth International Conference on Social Science Methodology: Recent Developments and Applications in Social Research Methodology. Amsterdam: Barbara Budrich Publisher: 1-19.

Binstock, G. (2010). Tendencias sobre la convivencia, matrimonio y maternidad en áreas urbanas de Argentina. Revista Latinoamericana de Población 3(6): 129146.

Binstock, G. and Cabella, W. (2011). La nupcialidad en el Cono Sur: evolución reciente en la formación de uniones en Argentina, Chile y Uruguay. In: Binstock G. and Melo J. (Eds.). Nupcialidad y familia en la América Latina actual. Rio de Janeiro: ALAP: 35-60.

Brown, S.L. (2000). Union Transitions Among Cohabitors: The Significance of Relationship Assessments and Expectations. Journal of Marriage and Family. 62(3): 833-846. doi:10.1111/j.1741-3737.2000.00833.x.

Bumpass, L.L., Sweet, J.A., and Cherlin, A. (1991). The role of cohabitation in declining rates of marriage. Journal of Marriage and the Family 53(4): 913-927. doi:10.2307/352997.

Castro-Martin, T. (2002). Consensual unions in Latin America: Persistence of a dual nuptiality system. Journal of Comparative Family Studies. 33(1): 35-55.

Caulfield, S. (2001). The history of gender in the historiography of Latin America. The Hispanic American Historical Review 81(3-4): 449-90. doi:10.1215/0018216881-3-4-449.

Covre-Sussai, M., and Matthijs, K. (2010). Socio-economic and cultural correlates of cohabitation in Brazil. Paper presented at Chaire Quételet Conference, Louvainla-Neuve, Belgium, 24-26 November 2010. 
De Vos, S. (1998). Nuptiality in Latin America: The view of a sociologist and family demographer. Wisconsin-Madison: Center for Demography and Ecoligy (CDE Working Paper 98-21).

Esteve, A., García-Román, J., Lesthaeghe, R., and Lopez-Gay, A. (2013). The "Second Demographic Transition" Features in Latin America: the 2010 Update. [Unpublished Manuscript]. Barcelona: Centre d'Estudis Demogràfics.

Esteve, A., Lesthaeghe, R., and López-Gay, A. (2012). The Latin American cohabitation boom, 1970-2007. Population and Development Review 38(1): 5581. doi:10.1111/j.1728-4457.2012.00472.x.

Fernández-Aceves, M. T. (2007). Imagined Communities: Women's History and the History of Gender in Mexico. Journal of Women's History 19(1): 200-205. doi:10.1353/jowh.2007.0010.

Freyre, G. (2000). Casa grande e senzala: formação da familia brasileira sob o regime de economia patriarcal. Rio de Janeiro, RJ: Record.

García, B. and de Oliveira, O. (2011). Family Changes and Public Policies in Latin America. Annual Review of Sociology 37(1): 593-611. doi:10.1146/annurev-soc081309-150205.

Goode, W.J. (1960). Illegitimacy in the Caribbean social structure. American Sociological Review 25(1): 21-30. doi:10.2307/2088944.

Goode, W.J. (1961). Illegitimacy Anomie and cultural penetration. American Sociological Review 26(6): 910-925. doi:10.2307/2090576.

Greene, M.E. and Rao, V. (1995). The Marriage Squeeze and the Rise in Informal Marriage in Brazil. Biodemography and Social Biology 42(1-2): 65-82. doi:10.1080/19485565.1995.9988888.

Heaton, T.B., Forste, R., and Otterstrom, S.M. (2002). Family transitions in Latin America: first intercourse, first union and first birth. International Journal of Population Geography 8(1): 1-15. doi:10.1002/ijpg.234.

Heuveline, P., and Timberlake, J. (2004). The role of cohabitation in family formation: The United States in comparative perspective. Journal of Marriage and the Family 66(5): 1214-1230. doi:10.1111/j.0022-2445.2004.00088.x.

Hiekel, N., Liefbroer, A.C., and Poortman, A.-R. (2012). The meaning of cohabitation across Europe. Paper presented at European Population Conference, Stockholm, Sweden, 13-16 June 2012. 
Holt, K. (2005). Marriage Choices in a Plantation Society: Bahia, Brazil. International Review of Social History 50(S13): 25-41. doi:10.1017/S0020859005002051

Horn, J.L., and McArdle, J.J. (1992). A practical and theoretical guide to measurement invariance in aging research. Experimental Aging Research 18(3): 117-44. doi:10.1080/03610739208253916

Johnson, T.P. (1998). Approaches to Equivalence in Cross-Cultural and Cross-National Survey Research. ZUMA Nachrichten Spezial, Cross-Cultural Survey Equivalence 3: 1-40.

Kalmijn, M. (2011). The Influence of Men's Income and Employment on Marriage and Cohabitation: Testing Oppenheimer's Theory in Europe. European Journal of Population 27(3): 269-293. doi:10.1007/s10680-011-9238-x.

Kankaras, M., Moors, G., and Vermunt, J.K. (2011). Testing for measurement invariance with latent class analysis. In: Davidov, E., Schmidt, P., and Billiet, J. (Eds.): Cross-cultural analysis. Methods and applications. United Kingdom: Taylor and Francis: 359-384.

Kiernan, K. (2001). The rise of cohabitation and childbearing outside marriage in western Europe. International Journal of Law, Policy and the Family 15(1): 121. doi:10.1093/lawfam/15.1.1.

Kiernan, K. (2004). Redrawing the boundaries of marriage. Journal of Marriage and the Family 66(4): 980-987. doi:10.1111/j.0022-2445.2004.00068.x.

Kiernan, K., McLanahan, S., Holmes, J., and Wright, M. (2011). Fragile Families in the US and UK. Universidad de Navarra: Center for Research on Child Wellbeing, Woodrow Wilson School of Public and International Affairs. (WP11-04FF).

Lesthaeghe, R. (2010). The unfolding story of the second demographic transition. Population and Development Review 36(2): 211-251. doi:10.1111/j.1728-4457. 2010.00328.x.

Lesthaeghe, R. and van de Kaa, D.J. (1986). Twee Demografische Transities. In: Lesthaeghe, R. and van de Kaa, D.J. (Eds.): Groei of Krimp?. Deventer: Van Loghum-Slaterus: 9-24

Manning, W.D. and Cohen, J.A. (2012). Premarital Cohabitation and Marital Dissolution: An Examination of Recent Marriages. Journal of Marriage and the Family 74(2): 377-387. doi:10.1111/j.1741-3737.2012.00960.x. 
McCutcheon, A.L. (2002). Basic concepts and procedures in Single and MultipleGroup Latent Class Analysis. In: Hagenaars, J.A. and McCutcheon, A.L. (Eds.): Applied latent class analysis. Cambridge: Cambridge University Press: 56-85. doi:10.1017/CBO9780511499531.003.

Minnesota Population Center. (2011). Integrated Public Use Microdata Series, International: Version 6.1 [Machine-readable database]. Minneapolis: University of Minnesota.

Parrado, E. and Tienda, M. (1997). Women's roles and family formation in Venezuela: New forms of consensual unions? Social Biology 44(1): 1-24. doi:10.1080/ 19485565.1997.9988931.

Prinz, C. (1995). Cohabiting, Married or Single: Portraying, Analyzing and Modelling New Living Arrangements in the Changing Societies of Europe. Avebury: Aldershot.

Quilodrán-Salgado, J. (2011). ¿Un modelo de nupcialidad postransicional en América Latina? In: Binstock, G. and Melo, J. (Eds.): Nupcialidad y familia en la América Latina actual. Rio de Janeiro: ALAP: 11-33.

Ribeiro, D. (1997). O povo brasileiro: a formação e sentido do Brasil. São Paulo, SP: Companhia das Letras.

Rutstein, S.O. and Rojas, G. (2003). Guide to DHS Statistics. Calverton, Maryland.

Samara, E.D.M. and da Costa, D.I.P. (1997). Family, Patriarchalism, and Social Change in Brazil. Latin American Research Review 32(1): 212-225.

Sassler, S. and Miller, A. J. (2011). Class Differences in Cohabitation Processes. Family Relations 60(2): 163-177. doi:10.1111/j.1741-3729.2010.00640.x.

Sobotka, T. and Toulemon, L. (2008). Changing family and partnership behaviour: Common trends and persistent diversity across Europe. Demographic Research 19(6): 85-138. doi:10.4054/DemRes.2008.19.6.

Surkyn, J. and Lesthaeghe, R. (2004). Value Orientations and the Second Demographic Transition (SDT) in Northern, Western and Southern Europe: An Update. Demographic Research S3(3): 45-86. doi:10.4054/DemRes.2004.S3.3.

United Nations, Department of Economic and Social Affairs. (2013). World Marriage Data 2012. (POP/DB/Marr/Rev2012).

Van de Kaa, D.J. (1987). Europe's Second Demographic Transition. Population Bulletin 42(1): 1-59. 
Covre-Sussai et al.: Traditional and modern cohabitation in Latin America

Vermunt, J.K. and Magidson, J. (2005). Latent GOLD 4.0 User's Guide. Belmont, Massachussetts: Statistical Innovations Inc.

Vignoli-Rodríguez, J. (2005). Unión y cohabitación en América Latina: ¿modernidad, exclusión, diversidad?. Santiago de Chile: ECLAC, United Nations. 


\section{Appendix 1: Data description ${ }^{17}$}

\section{Table A1: Proportion of partnered women by marital status in Latin America} (2000s)

\begin{tabular}{lccccc}
\hline Country & $\begin{array}{c}\text { First union: } \\
\text { Marriage }\end{array}$ & $\begin{array}{c}\text { First union: } \\
\text { Cohabitation }\end{array}$ & $\begin{array}{c}\text { Higher order } \\
\text { Marriage }\end{array}$ & $\begin{array}{c}\text { Higher order } \\
\text { Cohabitation }\end{array}$ & Total \\
\hline Bolivia & 5992 & 3255 & 220 & 678 & 10145 \\
& $59.1 \%$ & $32.1 \%$ & $2.2 \%$ & $6.7 \%$ & $100 \%$ \\
Brazil & 5230 & 2887 & 338 & 1484 & 9939 \\
& $52.6 \%$ & $29.0 \%$ & $3.4 \%$ & $14.9 \%$ & $100 \%$ \\
Colombia & 8346 & 12627 & 794 & 5629 & 27396 \\
& $30.5 \%$ & $46.1 \%$ & $2.9 \%$ & $20.5 \%$ & $100 \%$ \\
Dominican Republic & 2812 & 6773 & 619 & 5169 & 15373 \\
Honduras & $18.3 \%$ & $44.1 \%$ & $4.0 \%$ & $33.6 \%$ & $100 \%$ \\
Nicaragua & 4696 & 4732 & 470 & 1805 & 11703 \\
& $40.1 \%$ & $40.4 \%$ & $4.0 \%$ & $15.4 \%$ & $100 \%$ \\
Guyana & 3226 & 2589 & 478 & 1375 & 7668 \\
& $42.1 \%$ & $33.8 \%$ & $6.2 \%$ & $17.9 \%$ & $100 \%$ \\
Peru & 1617 & 823 & 169 & 368 & 2977 \\
& $54.3 \%$ & $27.6 \%$ & $5.7 \%$ & $92.4 \%$ & $100 \%$ \\
Latin America & 4043 & 4372 & 218 & $9.6 \%$ & 9554 \\
& $42.3 \%$ & $45.8 \%$ & $3.3 \%$ & 17429 & $100 \%$ \\
\hline
\end{tabular}

† Selected sample

Table A2: Proportion of first and higher order cohabitations in Latin America (2000s)

\begin{tabular}{lccc}
\hline Country & $\begin{array}{c}\text { First union: } \\
\text { Cohabitation }^{\dagger}\end{array}$ & $\begin{array}{c}\text { Higher order } \\
\text { Cohabitation }\end{array}$ & Total \\
\hline Bolivia & 3255 & 678 & 3933 \\
& $32.1 \%$ & $6.7 \%$ & $100 \%$ \\
Brazil & 2887 & 1484 & 4371 \\
& $29.0 \%$ & $14.9 \%$ & $100 \%$ \\
Colombia & 12627 & 5629 & 18256 \\
& $46.1 \%$ & $20.5 \%$ & $67 \%$ \\
Dominican Republic & 6773 & 5169 & 11942 \\
& $44.1 \%$ & $33.6 \%$ & $78 \%$ \\
Honduras & 4732 & 1805 & 6537 \\
Nicaragua & $40.4 \%$ & $15.4 \%$ & $56 \%$ \\
& 2589 & 1375 & 3964 \\
Guyana & $33.8 \%$ & $17.9 \%$ & $52 \%$ \\
& 823 & 368 & 1191 \\
Peru & $27.6 \%$ & $12.4 \%$ & $40 \%$ \\
& 4372 & 921 & 5293 \\
Latin America & $45.8 \%$ & $9.6 \%$ & $55 \%$ \\
& 38058 & 17429 & 55487 \\
\hline
\end{tabular}

${ }^{\dagger}$ Selected sample

${ }^{17}$ Listwise deletion for missing values 
Covre-Sussai et al.: Traditional and modern cohabitation in Latin America

Table A3: Latin American country by occurrence of pre-cohabitation pregnancy

\begin{tabular}{lccc}
\hline Country & No & Yes & Total \\
\hline Brazil & 2016 & 863 & 2879 \\
& $70.0 \%$ & $30.0 \%$ & $100.0 \%$ \\
Bolivia & 1818 & 1437 & 3255 \\
& $55.9 \%$ & $44.1 \%$ & $100.0 \%$ \\
Colombia & 7572 & 5055 & 12627 \\
& $60.0 \%$ & $40.0 \%$ & $100.0 \%$ \\
Dominican & 5452 & 1321 & 6773 \\
Honduras & $80.5 \%$ & $19.5 \%$ & $100.0 \%$ \\
& 3985 & 747 & 4732 \\
Guyana & $84.2 \%$ & $15.8 \%$ & $100.0 \%$ \\
Nicaragua & 511 & 312 & 823 \\
& $62.1 \%$ & $37.9 \%$ & $100.0 \%$ \\
Peru & 1124 & 257 & 1381 \\
& $81.4 \%$ & $18.6 \%$ & $100.0 \%$ \\
Latin America & 2788 & 1584 & 4372 \\
& $63.8 \%$ & $36.2 \%$ & $100.0 \%$ \\
\end{tabular}

Table A4: Latin American country by age at start of cohabitation

\begin{tabular}{|c|c|c|c|c|c|}
\hline \multirow{2}{*}{ Country } & \multirow{2}{*}{$\begin{array}{c}\text { Younger than } 15 \\
\text { years old }\end{array}$} & \multicolumn{2}{|c|}{ Between 16 and 19 Between 20 and 25} & \multirow{2}{*}{$\begin{array}{l}\text { Older than } 25 \\
\text { years old }\end{array}$} & \multirow{2}{*}{ Total } \\
\hline & & years old & years old & & \\
\hline \multirow{2}{*}{ Brazil } & 493 & 970 & 1022 & 392 & 2877 \\
\hline & $17.1 \%$ & $33.7 \%$ & $35.5 \%$ & $13.6 \%$ & $100.0 \%$ \\
\hline \multirow{2}{*}{ Bolivia } & 528 & 1089 & 1238 & 400 & 3255 \\
\hline & $16.2 \%$ & $33.5 \%$ & $38.0 \%$ & $12.3 \%$ & $100.0 \%$ \\
\hline \multirow{2}{*}{ Colombia } & 2164 & 3909 & 4652 & 1902 & 12627 \\
\hline & $17.1 \%$ & $31.0 \%$ & $36.8 \%$ & $15.1 \%$ & $100.0 \%$ \\
\hline \multirow{2}{*}{ Dominican Republic } & 1922 & 2501 & 1999 & 351 & 6773 \\
\hline & $28.4 \%$ & $36.9 \%$ & $29.5 \%$ & $5.2 \%$ & $100.0 \%$ \\
\hline \multirow{2}{*}{ Honduras } & 1325 & 1772 & 1365 & 270 & 4732 \\
\hline & $28.0 \%$ & $37.4 \%$ & $28.8 \%$ & $5.7 \%$ & $100.0 \%$ \\
\hline \multirow{2}{*}{ Guyana } & 142 & 293 & 284 & 104 & 823 \\
\hline & $17.3 \%$ & $35.6 \%$ & $34.5 \%$ & $12.6 \%$ & $100.0 \%$ \\
\hline \multirow[b]{2}{*}{ Nicaragua } & 466 & 529 & 329 & 57 & 1381 \\
\hline & $33.7 \%$ & $38.3 \%$ & $23.8 \%$ & $4.1 \%$ & $100.0 \%$ \\
\hline \multirow{2}{*}{ Peru } & 639 & 1374 & 1733 & 626 & 4372 \\
\hline & $14.6 \%$ & $31.4 \%$ & $39.6 \%$ & $14.3 \%$ & $100.0 \%$ \\
\hline \multirow{2}{*}{ Latin America (total) } & 7679 & 12437 & 12622 & 4102 & 36840 \\
\hline & $20.8 \%$ & $33.8 \%$ & $34.3 \%$ & $11.1 \%$ & $100.0 \%$ \\
\hline
\end{tabular}


Table A5: Latin American country by children - age at first child

\begin{tabular}{|c|c|c|c|c|c|c|c|}
\hline Country & No child & $\begin{array}{l}1 \text { or } 2 \text { children, } \\
\text { mother } \\
\text { younger than } \\
20 \text { years old }\end{array}$ & $\begin{array}{c}1 \text { or } 2 \text { children, } \\
\text { mother between } \\
20 \text { and } 30 \text { years } \\
\text { old }\end{array}$ & $\begin{array}{l}\text { Mother } \\
\text { older } \\
\text { than } 30 \\
\text { years }\end{array}$ & $\begin{array}{c}\text { More than } 2 \\
\text { children, mother } \\
\text { younger than } 20 \\
\text { years old }\end{array}$ & $\begin{array}{c}\text { More than } 2 \\
\text { children, mother } \\
\text { between } 20 \text { and } 30 \\
\text { years old }\end{array}$ & Total \\
\hline \multirow{2}{*}{ Brazil } & 506 & 778 & 745 & 96 & 528 & 232 & 2885 \\
\hline & $17.5 \%$ & $27.0 \%$ & $25.8 \%$ & $3.3 \%$ & $18.3 \%$ & $8.0 \%$ & $100.0 \%$ \\
\hline \multirow{2}{*}{ Bolivia } & 321 & 881 & 704 & 63 & 863 & 423 & 3255 \\
\hline & $9.9 \%$ & $27.1 \%$ & $21.6 \%$ & $1.9 \%$ & $26.5 \%$ & $13.0 \%$ & $100.0 \%$ \\
\hline \multirow{2}{*}{ Colombia } & 1474 & 3398 & 3324 & 391 & 2652 & 1388 & 12627 \\
\hline & $11.7 \%$ & $26.9 \%$ & $26.3 \%$ & $3.1 \%$ & $21.0 \%$ & $11.0 \%$ & $100.0 \%$ \\
\hline Dominican & 799 & 1483 & 1232 & 108 & 2110 & 1041 & 6773 \\
\hline Republic & $11.8 \%$ & $21.9 \%$ & $18.2 \%$ & $1.6 \%$ & $31.2 \%$ & $15.4 \%$ & $100.0 \%$ \\
\hline \multirow{2}{*}{ Honduras } & 517 & 1356 & 792 & 62 & 1408 & 597 & 4732 \\
\hline & $10.9 \%$ & $28.7 \%$ & $16.7 \%$ & $1.3 \%$ & $29.8 \%$ & $12.6 \%$ & $100.0 \%$ \\
\hline \multirow{2}{*}{ Guyana } & 98 & 194 & 159 & 20 & 239 & 113 & 823 \\
\hline & $11.9 \%$ & $23.6 \%$ & $19.3 \%$ & $2.4 \%$ & $29.0 \%$ & $13.7 \%$ & $100.0 \%$ \\
\hline \multirow{2}{*}{ Nicaragua } & 67 & 365 & 219 & 17 & 508 & 205 & 1381 \\
\hline & $4.9 \%$ & $26.4 \%$ & $15.9 \%$ & $1.2 \%$ & $36.8 \%$ & $14.8 \%$ & $100.0 \%$ \\
\hline \multirow{2}{*}{ Peru } & 403 & 1053 & 1201 & 146 & 986 & 583 & 4372 \\
\hline & $9.2 \%$ & $24.1 \%$ & $27.5 \%$ & $3.3 \%$ & $22.6 \%$ & $13.3 \%$ & $100.0 \%$ \\
\hline Latin America & 4185 & 9508 & 8376 & 903 & 9294 & 4582 & 36848 \\
\hline (total) & $11.4 \%$ & $25.8 \%$ & $22.7 \%$ & $2.5 \%$ & $25.2 \%$ & $12.4 \%$ & $100.0 \%$ \\
\hline
\end{tabular}

Table A6: Latin American country by age at time of the survey

\begin{tabular}{lcccc}
\hline Country & $\begin{array}{c}\text { Younger than 26 } \\
\text { years old }\end{array}$ & $\begin{array}{c}\text { Between 26 and 36 } \\
\text { years old }\end{array}$ & $\begin{array}{c}\text { Older than 36 } \\
\text { years old }\end{array}$ & Total \\
\hline Brazil & 1189 & 1109 & 589 & 2887 \\
Bolivia & $41.2 \%$ & $38.4 \%$ & $20.4 \%$ & $100.0 \%$ \\
& 1466 & 1262 & 527 & 3255 \\
Colombia & $45.0 \%$ & $38.8 \%$ & $16.2 \%$ & $100.0 \%$ \\
& 4552 & 4524 & 3551 & 12627 \\
Dominican Republic & $36.0 \%$ & $35.8 \%$ & $28.1 \%$ & $100.0 \%$ \\
Honduras & 2555 & 2280 & 1938 & 6773 \\
& $37.7 \%$ & $33.7 \%$ & $28.6 \%$ & $100.0 \%$ \\
Guyana & 2294 & 1521 & 917 & 4732 \\
& $48.5 \%$ & $32.1 \%$ & $19.4 \%$ & $100.0 \%$ \\
Nicaragua & 328 & 290 & 205 & 823 \\
& $39.9 \%$ & $35.2 \%$ & $24.9 \%$ & $100.0 \%$ \\
Peru & 562 & 498 & 321 & 1381 \\
& $40.7 \%$ & $36.1 \%$ & $23.2 \%$ & $100.0 \%$ \\
Latin America & 1502 & 1747 & 1123 & 4372 \\
& $34.4 \%$ & $40.0 \%$ & $25.7 \%$ & $100.0 \%$ \\
\hline
\end{tabular}


Covre-Sussai et al.: Traditional and modern cohabitation in Latin America

Table A7: Latin American country by educational attainment

\begin{tabular}{lccccc}
\hline Country & No education & Primary & Secondary & Higher & Total \\
\hline Brazil & 12 & 1718 & 942 & 136 & 2808 \\
& $0.4 \%$ & $61.2 \%$ & $33.5 \%$ & $4.8 \%$ & $100.0 \%$ \\
Bolivia & 138 & 1791 & 1072 & 254 & 3255 \\
& $4.2 \%$ & $55.0 \%$ & $32.9 \%$ & $7.8 \%$ & $100.0 \%$ \\
Colombia & 368 & 3953 & 6385 & 1921 & 12627 \\
& $2.9 \%$ & $31.3 \%$ & $50.6 \%$ & $15.2 \%$ & $100.0 \%$ \\
Dominican & 400 & 3234 & 2332 & 807 & 6773 \\
\multirow{2}{*}{ Honduras } & $5.9 \%$ & $47.7 \%$ & $34.4 \%$ & $11.9 \%$ & $100.0 \%$ \\
& 444 & 3373 & 857 & 58 & 4732 \\
Guyana & $9.4 \%$ & $71.3 \%$ & $18.1 \%$ & $1.2 \%$ & $100.0 \%$ \\
\multirow{2}{*}{ Nicaragua } & 25 & 217 & 549 & 32 & 823 \\
\multirow{2}{*}{ Peru } & $3.0 \%$ & $26.4 \%$ & $66.7 \%$ & $3.9 \%$ & $100.0 \%$ \\
& 343 & 651 & 342 & 45 & 1381 \\
Latin America & $24.8 \%$ & $47.1 \%$ & $24.8 \%$ & $3.3 \%$ & $100.0 \%$ \\
& 182 & 1499 & 1877 & 814 & 4372 \\
& $4.2 \%$ & $34.3 \%$ & $42.9 \%$ & $18.6 \%$ & $100.0 \%$ \\
\end{tabular}




\section{Appendix 2: Multiple Group Latent Class Analysis}

The general Latent Class model proposed in this study can be expressed through Equation 1 (McCutcheon 2002, p.58):

$$
\pi_{i j k l t}^{A B C D X}=\pi_{t}^{X} \pi_{i t}^{A \mid X} \pi_{j t}^{B \mid X} \pi_{k t}^{C \mid X} \pi_{l t}^{D \mid X}
$$

where $\mathrm{A}, \mathrm{B}, \mathrm{C}$, and $\mathrm{D}$ represent the observed indicators and $\mathrm{i}, \mathrm{j}, \mathrm{k}$, and $\mathrm{l}$ represent their respective categories. $\mathrm{X}$ refers to the latent classification variable, which has $\mathrm{t}$ classes. The model contains two types of parameter, namely conditional response probabilities and latent class probabilities. Conditional response probability, $\pi_{i t}^{A \mid X}$, is the probability of being located in the category (i) of the observed variable (A), given that the individual is a member of the latent class $(\mathrm{t})$. The conditional response probabilities indicate how likely it is that a category of the observed variables is reported by the members of the different classes. As such, they designate the strength of the association between the latent classes and the indicators. Latent class probabilities, $\pi_{t}^{X}$, represent how the observations in the sample are distributed over the latent typology (McCutcheon 2002).

Because we use DHS data from eight countries and want to compare the latent class model among those eight countries, we have extended our latent class model to a multiple group latent class (MGLCA) model. This implies that a grouping variable (by country) is added, and that latent class parameters (i.e., conditional probabilities and latent class probabilities) can be estimated for the groups separately. Equation (2) formalizes the general MGLCA model (McCutcheon 2002, p.77):

$$
\pi_{i j k l t s}^{A B C D X G}=\pi_{s}^{G} \pi_{t s}^{X \mid G} \pi_{i t s}^{A \mid X G} \pi_{j t s}^{B \mid X G} \pi_{k t s}^{C \mid X G} \pi_{l t s}^{D \mid X G}
$$

Here, (s) indicates the membership of the grouping variable $(\mathrm{G})$ and the conditional probability of class membership is now conditional on group membership. The model formalized in Equation (2) is called the heterogeneous model, since conditional probabilities and latent class probabilities are allowed to vary across groups. In this situation, however, it is not possible to make valid comparisons of the results across groups.

In order to compare the latent classification across groups it is necessary to test whether measurement invariance (or equivalence) is present. By imposing cross-group equality restrictions on conditional probabilities, various levels of measurement equivalence can be assessed (Kankaras et al. 2011). Concretely, testing for measurement equivalence involves testing whether a model is completely 
homogeneous, structurally homogeneous, or only partially homogeneous, against the hypothesis that it is completely heterogeneous.

Figure 5 contains a graphic representation of these various levels of measurement equivalence, ordered from less to more restrictive.

\section{Figure 5: Levels of measurement invariance}

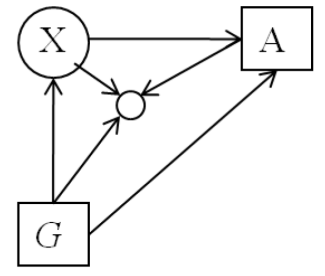

(a) Complete Heterogeneity

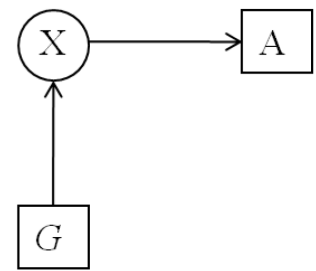

(c) Structural Homogeneity

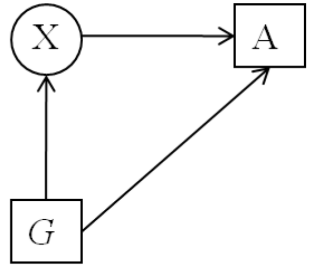

(b) Partial Homogeneity

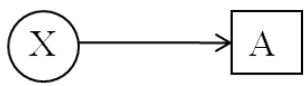

\section{G}

(d) Complete Homogeneity

Note: Based on the illustration proposed by Kankaras et al. (2011), p.367.

The complete heterogeneity model (Figure 5a) is the model described in Equation (2), and assumes no equality of parameters across the groups (in our case Latin American countries). The partial homogeneity model (Figure 5b) restricts the relationships between the latent variable and the observed variables (slopes) to being the same, but allows for group-specific conditional response probabilities (intercepts). In the structurally homogeneous model (Figure 5c), both intercept and slope parameters are constrained to be the same across groups. This model implies that distributions of the observed variables within the latent classes (i.e., conditional probabilities) are independent of the grouping variable (countries). Latent class probabilities (i.e., the distribution of different types of cohabitation in the population), however, are still allowed to vary over groups. Finally, in the complete homogeneity model (Figure 5d) all parameters are restricted to be equal across groups, indicating that there is no group difference in terms of intercepts, slopes, and class size (Kankaras et al. 2011). Since we 
want to verify differences across groups, the complete homogeneity model is less relevant for this study.

This MGLCA framework is particularly relevant for the research question at hand: it will identify whether different types of cohabitation (latent classes) exist. These cohabitation types are not observed directly but are inferred from interrelations between observed characteristics such as the age at start of cohabitation and the number of children. The typology of cohabitations will then be compared over eight Latin American countries (groups). Before this comparison can be made, however, measurement equivalence will be tested applying the procedure proposed by Kankaras et al. (2011, pp. 367-374) ${ }^{18}$. Following this procedure, the number of latent classes should be firstly determined for each group separately and then for the pooled data with all countries together in the same dataset. If the number of latent classes is the same for each country and the pooled data, the heterogeneous model is fitted to the data as a baseline model. Next, a series of nested models is tested in which equality restrictions are applied. These models are evaluated in terms of model fit and comparability is attested if the restrictions do not deteriorate the model goodness of fit. Subsequently, we perform an item-level analysis to guarantee that the observed indicators are not sources of invariance. Finally the covariates (type of household, age, and education) are introduced into the model (Kankaras et al. 2011).

\footnotetext{
${ }^{18}$ Models were estimated with the Latent Gold 4.5 program (Vermunt and Magidson 2005).
} 
Covre-Sussai et al.: Traditional and modern cohabitation in Latin America

\section{Appendix 3: Item response and types of cohabitation probability (1980s and 1990s)}

\begin{tabular}{|c|c|c|c|c|c|c|}
\hline \multirow{2}{*}{ Response probabilities } & \multicolumn{3}{|c|}{ 1980s } & \multicolumn{3}{|c|}{ 1990s } \\
\hline & Class 1 & Class 2 & Class 3 & Class 1 & Class 2 & Class 3 \\
\hline \multicolumn{7}{|l|}{ Pre-cohabitation pregnancy } \\
\hline No & 0.78 & 1.00 & 0.00 & 0.76 & 1.00 & 0.00 \\
\hline Yes & 0.22 & 0.00 & 1.00 & 0.24 & 0.00 & 1.00 \\
\hline \multicolumn{7}{|l|}{ Age at the start of cohabitation } \\
\hline Younger than 15 years old & 0.41 & 0.00 & 0.00 & 0.39 & 0.00 & 0.00 \\
\hline Between 16 and 19 years old & 0.58 & 0.09 & 0.06 & 0.61 & 0.14 & 0.07 \\
\hline Between 20 and 25 years old & 0.01 & 0.74 & 0.70 & 0.00 & 0.69 & 0.64 \\
\hline Older than 25 years & 0.00 & 0.17 & 0.24 & 0.00 & 0.17 & 0.30 \\
\hline \multicolumn{7}{|l|}{ Children - Age at first child } \\
\hline No child & 0.08 & 0.22 & 0.00 & 0.07 & 0.25 & 0.00 \\
\hline 1 or 2 children, mother younger than 20 years old & 0.38 & 0.00 & 0.18 & 0.43 & 0.00 & 0.18 \\
\hline 1 or 2 children, mother between 20 and 30 years old & 0.02 & 0.42 & 0.32 & 0.01 & 0.45 & 0.34 \\
\hline Mother older than 30 years & 0.00 & 0.06 & 0.02 & 0.00 & 0.06 & 0.03 \\
\hline More than 2 children, mother younger than 20 years old & 0.48 & 0.00 & 0.18 & 0.46 & 0.00 & 0.22 \\
\hline $\begin{array}{l}\text { More than } 2 \text { children, mother between } 20 \text { and } 30 \text { years } \\
\text { old }\end{array}$ & 0.03 & 0.30 & 0.30 & 0.03 & 0.25 & 0.23 \\
\hline \multicolumn{7}{|l|}{ Covariates } \\
\hline \multicolumn{7}{|l|}{ Age } \\
\hline Younger than 26 years old & 0.60 & 0.36 & 0.33 & 0.58 & 0.36 & 0.29 \\
\hline Between 26 and 36 years old & 0.25 & 0.45 & 0.47 & 0.28 & 0.41 & 0.47 \\
\hline Older than 36 years & 0.15 & 0.19 & 0.20 & 0.14 & 0.23 & 0.24 \\
\hline \multicolumn{7}{|l|}{ Education } \\
\hline No education & 0.13 & 0.11 & 0.13 & 0.11 & 0.07 & 0.08 \\
\hline Primary & 0.72 & 0.57 & 0.64 & 0.56 & 0.40 & 0.44 \\
\hline Secondary & 0.15 & 0.29 & 0.21 & 0.32 & 0.44 & 0.42 \\
\hline Higher & 0.00 & 0.03 & 0.02 & 0.01 & 0.09 & 0.06 \\
\hline \multicolumn{7}{|l|}{ Latent class proportions } \\
\hline Latin America & 0.51 & 0.30 & 0.19 & 0.45 & 0.33 & 0.21 \\
\hline Brazil & 0.42 & 0.32 & 0.26 & 0.39 & 0.33 & 0.29 \\
\hline Bolivia & 0.50 & 0.29 & 0.21 & 0.49 & 0.29 & 0.22 \\
\hline Colombia & 0.48 & 0.31 & 0.21 & 0.41 & 0.36 & 0.24 \\
\hline Dominican Republic & 0.63 & 0.31 & 0.06 & 0.59 & 0.35 & 0.06 \\
\hline \multicolumn{7}{|l|}{ Honduras } \\
\hline \multicolumn{7}{|l|}{ Nicaragua } \\
\hline \multicolumn{7}{|l|}{ Guyana } \\
\hline Peru & 0.53 & 0.27 & 0.21 & 0.41 & 0.34 & 0.25 \\
\hline
\end{tabular}

